U. S. Department of the Interior

Bureau of Land Management

Alaska State Office

222 West 7th Avenue

Anchorage Alaska 99513
BLM-Alaska Open File Report 82

BLM/AK/ST-01/001+9217+020

September 2000

\title{
Recovery of Lichen in \\ Tussock Tundra Following Fire in Northwestern Alaska
}

Randi R. Jandt and C. Randy Meyers

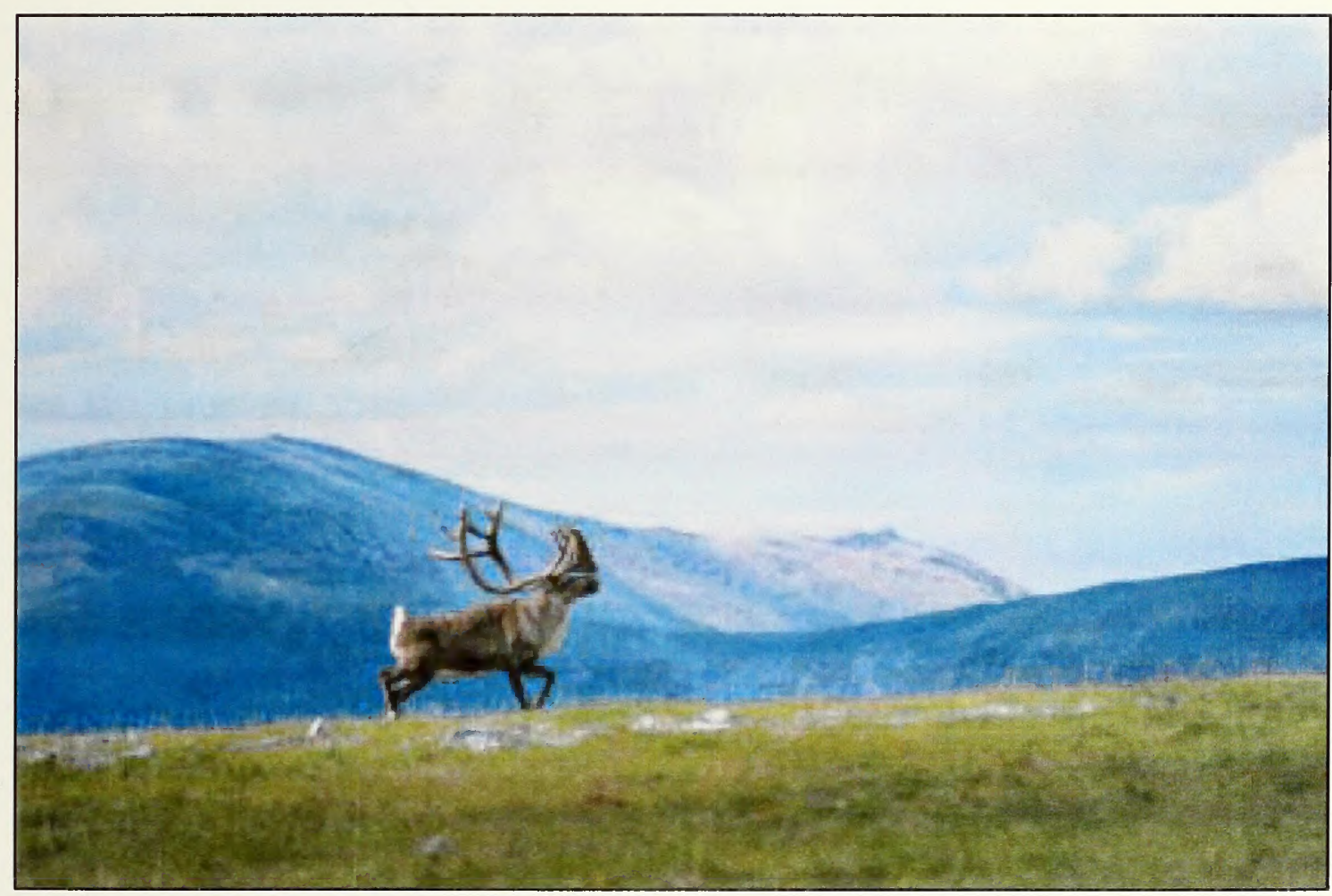




\section{Cover Photo}

Caribou bull from study sites on the Seward Peninsula in 1997 (photo Aaron Jokisch).

\section{Disclaimer}

The mention of trade names or commercial products in this report does not constitute endorsement or recommendation for use by the federal government.

\section{Authors}

Randi Jandt is a fire ecologist, Bureau of Land Management (BLM), Alaska Fire Service, 1541 Gaffney Road, Ft. Wainwright, Alaska 99703; and Randy Meyers is a botanist/natural resource specialist, BLM's Northern feild Office, P.O. Box 1049, Kotzebue, Alaska 99752. At the time of the study, Randi Jandt was wildlife biologist for the BLM Northern Field Office in Fairbanks, Alaska.

\section{Open File Reports}

Open File Reports issued by the Bureau of Land Management-Alaska present the results of inventories or other investigations on a variety of scientific and technical subjects that are made available to the public outside the formal BLM-Alaska technical publication series. These reports can include preliminary or incomplete data and are not published and distributed in quantity.

The reports are available while supplies last from BLM External Affairs, 222 West 7 th Avenue \#13, Anchorage, Alaska 99513 and from the Juneau Minerals Information Center, 100 Savikko Road, Mayflower Island, Douglas, AK 99824, (907) 364-1553. Copies are also available for inspection at the Alaska Resource Library and Information Service (Anchorage), the USDI Resources Library in Washington, D. C., various libraries of the University of Alaska, the BLM National Business Center Library (Denver) and other selected locations.

A complete bibliography of all BLM-Alaska scientific reports can be found on the Internet at: http:// www.ak.blm.gov/affairs/sci_rpts.html. Related publications are also listed at http://juneau.ak.blm.gov.

\section{The BLM Mission}

The Bureau of Land Management sustains the health, diversity and productivity of the public lands for the use and enjoyment of present and future generations. 


\section{Recovery of Lichen in Tussock Tundra Following Fire in Northwestern Alaska}

Randi R. Jandt and C. Randy Meyers

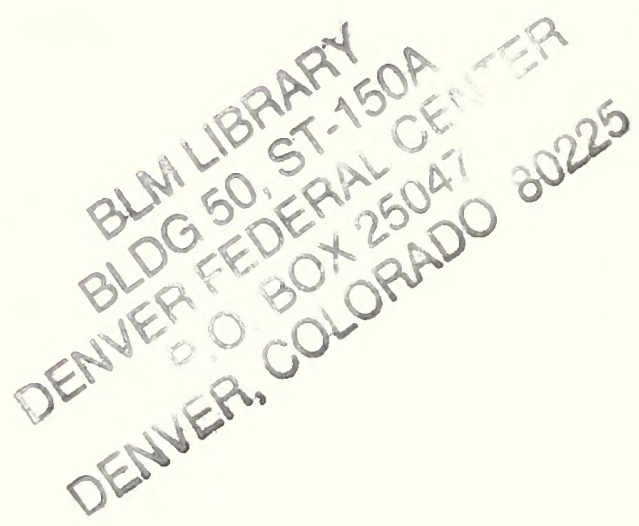





\section{Contents}

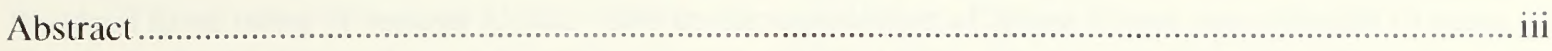

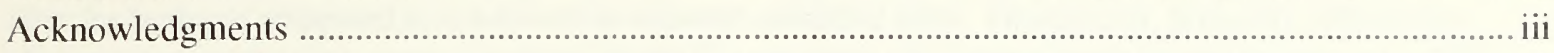

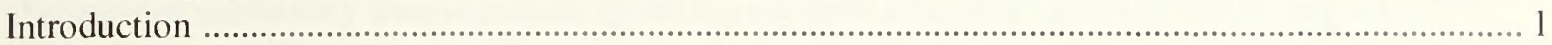

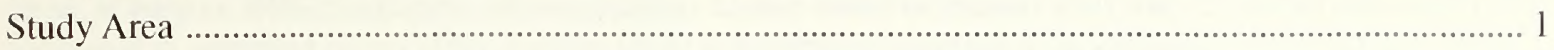

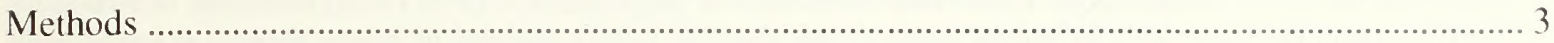

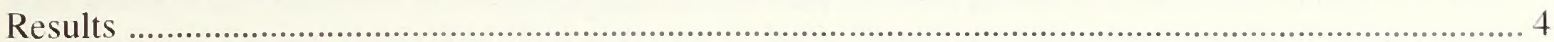

Post-fire Succession at Ulukluk Creek .................................................................................. 4

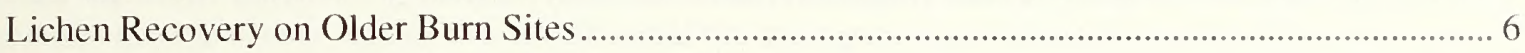

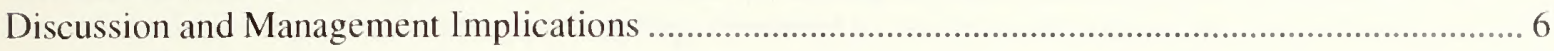

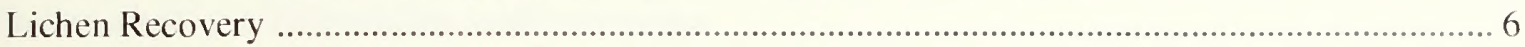

Recovery of Vascular Plants ................................................................................................ 7

Comparison of Point-frame and Canopy Cover Class Methods .............................................. 9

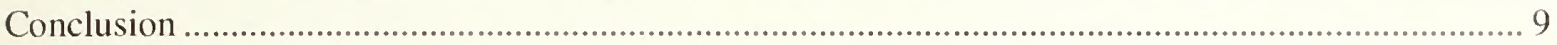

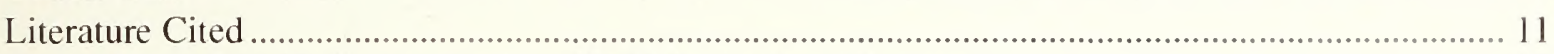

Appendix A: Tundra fire recovery at Ulukluk Creek study sites ......................................... 13

Appendix B: Transect one (T1) and Transect two (T2) at post-burn intervals ............................... 14

Appendix C: Three-year photoplot comparison ..................................................................... 16

Appendix D: Successional changes on individual quadrats at post-burn intervals,

Ulukluk Creek study site ....................................................................................... 18

Appendix E: Comparison of individual unburned control quadrats at the Ulukluk Creek study site ..... 20

Appendix F: Tundra fire recovery in western Alaska ............................................................... 21

Figure 1. Map location and plot layout ............................................................................ 2

Figure 2. Plant cover over time on burn and control transects, Buckland Valley ............................. 5

\section{Tables}

Table 1. Results of point-intercept sampling comparison of Ulukluk Creek transects ...................... 4

Table 2. Changes in vegetative canopy cover over time ......................................................... 5

Table 3. Comparison of burn severity index (BSI) and percent lichen cover ................................. 6

Table 4. Comparison of paired control and burned transects at two sites 20-25 years after fire 



\section{Abstract}

Paired permanent vegetative cover transects were established after a small ( 2 ha) 1981 tundra fire in the Buckland River valley of western Alaska. Data on the regeneration of forage lichens was collected 14 years after the burn and compared to conditions in adjacent unburned plots. Graminoids, primarily cottongrass (Eriophorum vaginatum), were stimulated by the fire and grew still more vigorously on the burn area (55\% cover in burn vs. $44 \%$ in adjacent unburned area). Lichen cover on burned plots had recovered very little ( $1 \%)$ compared to unburned plots $(15 \%)$. Further study is required to establish a regeneration curve, but data from older burns in tussock tundra in western Alaska indicate the recovery period for fire-disturbed ranges of the Western Arctic Caribou Herd (WACH) is well over 25 years. Recovery times appear similar to those reported for the Northwest Territories of Canada. Land and wildlife managers need information on lichen regeneration timelines specific to their regions to establish sound fire management guidelines for caribou (Rangifer tarandus) winter range. Point-intercept sampling, compared to canopy cover estimation, proved to be a more efficient sampling technique in the tundra cover type.

\section{Acknowledgments}

This study was supported by the BLM Northern Field Office in Fairbanks, Alaska. Several investigators were involved in background research, study design, and/or data collection, including Layne Adams (Research Biologist, USGS Biological Research Division, Anchorage, Alaska), Bruce Connery (Natural Resource Specialist, Acadia National Park, Maine), Melanie Miller (Fire Ecologist, BLM Fire and Aviation Policy Office in Boise, Idaho); and Keith Woodworth (Natural Resource Specialist) and Michelle Corrigan (Biotechnician), both of BLM-Alaska's Northern Field Office, Fairbanks, Alaska. 



\section{INTRODUCTION}

North American caribou (Rangifer tarandus) herds are largely dependent on lichens for winter forage. Prevalence of ground lichens in the winter diet has been estimated to be as high as 80-95\% in Canada (Beverly and Qamanirjuaq Caribou Management Board, 1994). Winter fecal pellets from caribou in the Buckland Valley consisted of $85 \%$ lichens in 17 composite samples (Jandt, unpublished data) indicating that lichen constitutes a major portion of the winter diet for the Western Arctic Caribou Herd, which winters in this area. Studies have shown that caribou will select for this high carbohydrate food when available, with lichens of the Cladina, Cladonia and Cetraria genera most frequently mentioned. Preference trials on reindeer in Finland suggested the following "reindeer lichens" in order of decreasing palatability: (Cladina rangiferina $>C$. stellaris $>C$. mitis $)>$ Cladonia uncialis $>$ Cetraria islandica $>$ Cetraria nivalis $>$ Alectoria spp. $>$

Stereocaulon spp. (Norberg et al. 1995).

A review of the literature for lichen reestablishment times found substantial differences reported from various geographic areas. Black and Bliss (1978) described black spruce stands in the lower Mackenzie Valley in Canada's Northwest Territories, where Cladina mitis first became important 120-200 years postfire. Stands dominated by lush growths of caribou-preferred lichen species such as Cladina stellaris (previously called Cladonia alpestris), Cladina rangiferina and Cetraria cucullata were frequently over 200 years old. In contrast, other locations in the Northwest Territories reported stands that had $38 \%$ cover of caribou lichens by 44 years and $65 \%$ cover by 92 years (Rowe et al. 1974). Differences in reestablishment times should be expected, as the time required depends on climate, fire severity, moisture regimes, soil types, etc. Based on surveys of four taiga stands in northcentral Canada, Scotter (1970) stated that it takes about 100 years for lichens to reach their former abundance after fire. Other investigators have reported shorter intervals for reestablishment (Miller 1976, Bergerud 1974, Pegau 1975).

Land managers need estimates of succession timelines for their specific regions so management plans for wildlife habitat and fire can be scientifically based. After review of existing knowledge of the ecological relationships of caribou, lichens and fire, Klein (1982:394) concludes: "Long-term monitoring of the responses of range vegetation to fires of differing intensities clearly should be a high priority of government agencies responsible for management of caribou range lands." This priority is reiterated in the BLM's Buckland Valley Habitat Management Plan (1983), which covers much of the winter range of the Western Arctic Caribou Herd. Data on the reestablishment times required by caribou forage lichens on tussock tundra communities that characterize the core winter range for the Western Arctic Caribou Herd are generally lacking in the scientific literature. On the herd's eastern ranges in the upper Kobuk Valley, Swanson (1996) found that C. stellaris and $C$. rangiferina increased almost five-fold on dry terraces and uplands older than 100 years compared to 10- to 50-year-old stands. In contrast, C. mitis and Cladonia spp. reached peak abundance in the 50- to 100 -year-old stands.

\section{STUDY AREA}

On 25 July 1981, a lightning-ignited fire burned approximately 2 ha of low shrubcottongrass (Eriophorum vaginatum) tussock tundra on Ulukluk Creek, $5 \mathrm{~km}$ south of the Buckland River (Fig. 1). The Buckland Valley is a broad plain spanning about $100 \mathrm{~km}$ between the Selawik Hills to the north and Talik Ridge to the south. Forested river valleys of the Kateel and Huslia rivers to the east are clearly differentiated from the predominantly treeless tundra of the Buckland valley. Treeless tundra continues to dominate the landscape on the Seward Peninsula west of the main study area. Mean biomass of live lichen in this region was estimated by Adams and Connery (1983) at $161 \pm 22 \mathrm{~g} / \mathrm{m}^{2}$, and vascular production at $64 \pm 5 \mathrm{~g} / \mathrm{m}^{2}$. Vegetation at the Ulukluk Creek study site was mapped and described by Swanson et al. (1985) as low shrub-cottongrass tussock tundra. Cottongrass, a classic example of the tussock growth form, forms large, compact tussocks $15-40 \mathrm{~cm}$ tall throughout arctic landscapes of Alaska and Canada (Hultén 1968, Porsild and Cody 1980). It was the dominant graminoid at our study sites. Transects at two older burn sites (Wagon 


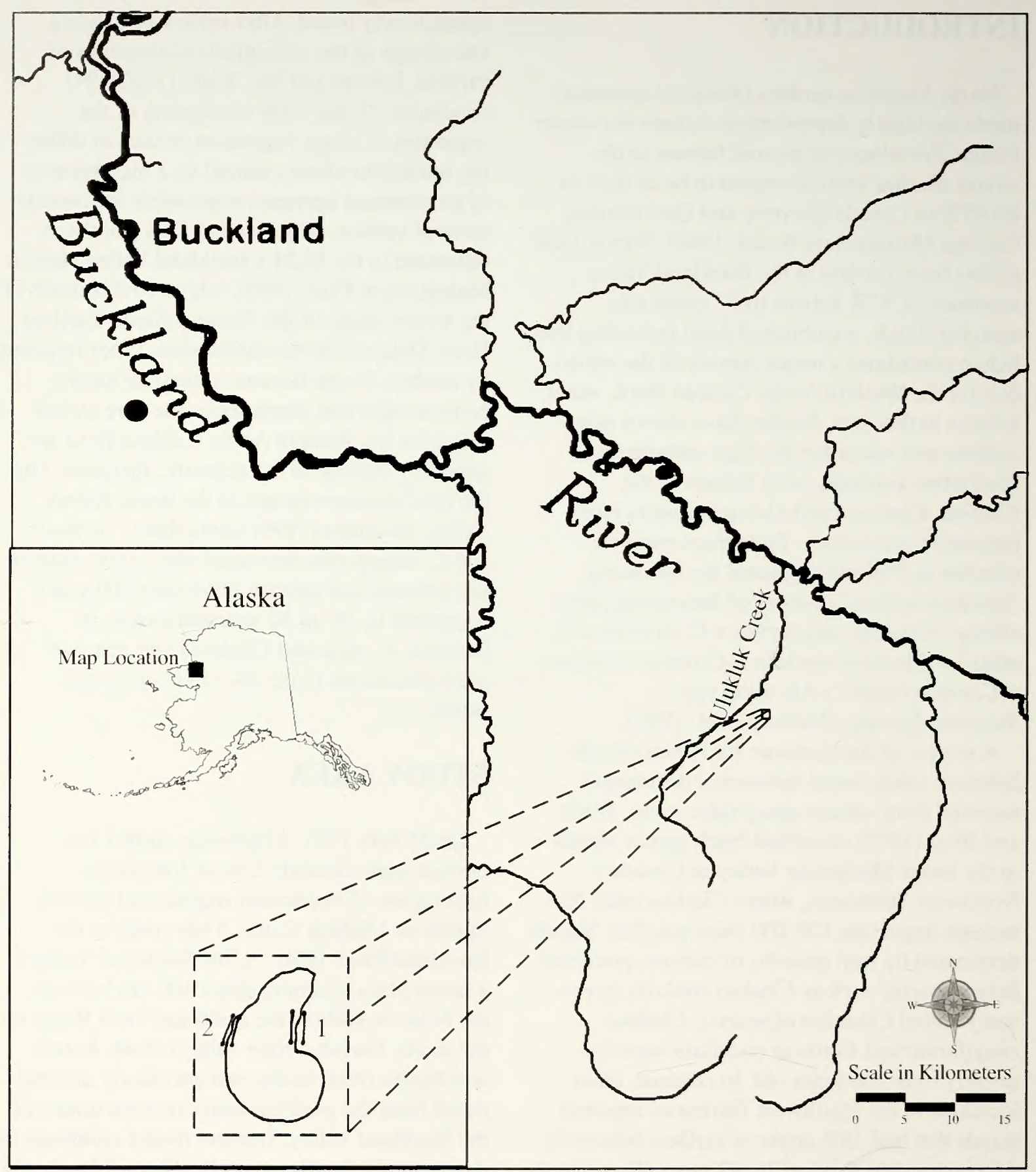

Figure 1. Map location and plot layout of Ulukluk Creek study site, northwestern Alaska. 
Wheel and Pargon River) farther west on the Seward Peninsula were placed in lichen tussock tundra. Low shrub-cottongrass tundra is an ecological site characterized by high cover values for shrubs (25-50\%) and graminoids (25$50 \%$ ), with moderately low amounts of lichen (6-12\%), and small values for forb cover $(0-6 \%)$. In contrast, the lichen tussock tundra ecological site typically has high cover values for lichens and shrubs (both 25-50\%), with moderate graminoid cover $(12-25 \%)$, and moderately low forb cover (6-12\%) (Swanson et al. 1985). Plant nomenclature follows Hultén (1968) for vascular plants and Thomson (1972) for lichens.

The Buckland Valley comprises an integral part of the winter range of the Western Arctic Caribou Herd - currently the largest caribou herd in the state and one of Alaska's major wildlife resources. A 1993 photocensus estimated a minimum herd size of 450,000 caribou (Machida and Dau 1995). The herd ranges over about $360,000 \mathrm{~km}^{2}$ of tundra and taiga habitat in northwest Alaska and calves mainly on the North Slope between the Lisburne Hills and the Colville River. The herd has been increasing in size, although more slowly in recent years, after a drastic decline between 1970 and 1976 when it dropped from 240,000 to 70,000 animals (Davis and Valkenburg 1978). The decline was thought to be caused largely by excessive human harvest, although predation, disease and possibly range conditions were also implicated.

Wildfires occur in the Buckland Valley and surrounding highlands, but they are not as frequent as in the spruce forests of interior Alaska. Over $90 \%$ of fires are caused by lightning and very large fires (>200,000 ha) occur about every 10 years. The BLM is responsible for fire management in most of this area. The current management policy is to monitor fires, natural or human-caused, rather than suppress fires unless they present a threat to human life or property. The BLM's current fire management goal is to achieve a natural fire regime.

\section{METHODS}

Two sets of permanent transects were established on 29 July 1981 to monitor recovery and succession of vegetation in the burn. Paired transects were located along the east and west flanks of the burn, one inside and one outside the burn perimeter (Fig. 1). Each $50 \mathrm{~m}$ transect was marked with reinforcing rod stakes and twenty-five 20 by $50 \mathrm{~cm}$ quadrats were spaced evenly along the transects. Transects $1 \mathrm{~A}$ and $1 \mathrm{~B}$ run $330^{\circ}$ along the eastern flank while Transects $2 \mathrm{~A}$ and $2 \mathrm{~B}$ run $320^{\circ}$ along the western perimeter. The severity of the burn at each transect was quantified by estimating the portion of each quadrat that corresponded to five fire severity classes used by Viereck et al. (1979): unburned, scorched, lightly burned, moderately burned and severely burned. Coverage within each burn severity class was estimated to the nearest $5 \%$.

Within quadrats, plant cover by species and by cover type (shrub, forb, lichen) was estimated within six percentage categories: 0-5\%, 6-25\%, $26-50 \%, 51-75 \%, 76-95 \%$ and $>95 \%$

(Daubenmire 1959). Cover values were recorded as the mean of the cover class (i.e. 2.5, 15, 37.5, etc.) for analysis. A Shannon diversity index was calculated for pooled burned and unburned transects (Ludwig and Reynolds 1988). Richness was estimated as the total number of species present anywhere along the transect. Photos were taken vertically over a 20 by $50 \mathrm{~cm}$ sampling frame every $5 \mathrm{~m}$ along each transect. Plots were surveyed during late summer in 1981, $1982,1983,1984$ and 1995. Due to staff turnover, transects were surveyed by a different observer pair after 1984.

After completing the Daubenmire sampling in 1995, sampling on each transect was repeated using a point-sampling frame, with 50 string intersections over a $0.5 \mathrm{~m}^{2}$ area (frame size: $1 \mathrm{~m}$ x $0.5 \mathrm{~m}$ ). The height was adjustable depending on the vegetation, from 0.25 to $0.5 \mathrm{~m}$. The first plant species encountered directly under an intersection was recorded as a hit. For this method 12 quadrats were located every $4 \mathrm{~m}$ along the transect, starting at $0 \mathrm{~m}$. Cover values were calculated as the number of hits on one species or cover class divided by the total number of points in a quadrat $(\mathrm{n}=50)$. Mean cover value was the average of all quadrats within the transect.

Only the canopy cover based on first hits is reported in this paper. The number of transects was small: four for Ulukluk Creek and two at Wagon Wheel and Paragon River. For areas with one transect in each treatment type, statistical inference for means and standard error is necessarily limited to the transect, whereas for 
Ulukluk Creek statistical inference is for the treatment areas, based on two samples of each. Thus, for Wagon Wheel and Pargon River, mean cover values for the transect based on quadrats are reported and for Ulukluk Creek mean cover (from both transects) of a given treatment and its associated standard error $(\sqrt[s]{n})$ are reported.

\section{RESULTS}

\section{Post-fire Succession at Ulukluk Creek}

Although visual contrast between the old burn in treeless tundra and the surrounding area was subtle, the fire boundary could still be detected from aerial reconnaissance. The burn appeared darker than surrounding vegetation, partly due to the absence of lichen cover and partly to the vigorous cottongrass revegetation. Closer inspection on the ground revealed some less-obvious differences, including dead stand- ing Labrador tea (Ledum palustre ssp. decumbens) shrubs and fire-damaged tussocks. On the burned transects, lichens had not recovered and the $<1 \%$ lichen cover that was recorded on point-intercept transects (Table 1) consisted primarily of Cladonia spp. squamules, which were difficult to positively identify. Scattered tiny tufts of Cladina mitis/arbuscula, $C$.

rangiferina and Cetraria cucullata were present in trace amounts. Graminoids, especially cottongrass, increased rapidly at Ulukluk Creek after the fire. Average cover of cottongrass rose from $<1 \%$ in 1981 to $>30 \%$ in 1984 , while unburned plots averaged $13-20 \%$ during this period (Table 2). Even 14 years after the burn, percent graminoid cover in the burned plots was still higher than any previous year surveyed (Fig. 2), and cottongrass cover values were $11 \%$ greater than the unburned plots (Table 1). Dwarf shrubs increased steadily over time on burned plots at Ulukluk Creek (Fig. 2). Burned plots averaged $31 \%$ shrub cover by 1995 , while

\begin{tabular}{l|c|c|c|c|c}
\hline \multirow{2}{*}{ COVER TYPE } & \multicolumn{5}{|c}{ TREATMENT } \\
\cline { 2 - 6 } & Unburned & SE (N=2) & Burned & SE (N=2) & Difference \\
\hline Carex spp. & 9.3 & 1.3 & 8.8 & 0.9 & -0.6 \\
Eriophorum spp. & 34.5 & 12.2 & 45.9 & 7.4 & +11.4 \\
$\quad$ Total Graminoid: & 43.8 & 10.8 & 54.7 & 6.5 & +10.8 \\
\hline Rubus chamaemorus & 2.3 & 0.3 & 2.0 & 0.5 & -0.3 \\
Other forb & 0.2 & - & 0.1 & - & -0.1 \\
Total Forb: & 2.5 & 0.2 & 2.1 & 0.4 & -0.4 \\
\hline Ledum palustre & 11.2 & 7.5 & 15.2 & 5.8 & +4.1 \\
Vaccinium uliginosum & 5.8 & 1.3 & 7.2 & 3.3 & +1.5 \\
Betula nana & 2.2 & 0.8 & 3.2 & 1.2 & +0.9 \\
Empetrum nigrum & 2.9 & 0.6 & 0.9 & 0.8 & -2.0 \\
Other shrub & 6.3 & - & 4.8 & - & -1.5 \\
Total Shrub: & 28.4 & 7.6 & 31.4 & 4.1 & +3.0 \\
\hline Cladonia rangiferina & 5.0 & 0.3 & 0.1 & 0.1 & $-4.9^{*}$ \\
Cladina mitis/arbuscula ${ }^{1}$ & 2.5 & 1.2 & 0.1 & 0.1 & -2.4 \\
Cetraria cucullata & 6.1 & 2.4 & 0.2 & 0.3 & -5.8 \\
C. islandica & 1.1 & 0.1 & 0.1 & 0.1 & $-1.0^{*}$ \\
Other lichen & 0.8 & - & 0.8 & - & 0.0 \\
Total Lichen: & 15.4 & 4.4 & 1.2 & 0.4 & $-14.2^{*}$ \\
\hline
\end{tabular}

* Significance as determined by Student's t-test, small sample inference for $n=2$ transects/treatment, $\mathrm{p}<0.05$.

${ }^{1}$ Species of lichens that cannot be distinguished without chemical tests.

Table 1. Results of point-intercept sampling comparison of Ulukluk Creek control and burn transects 14 years after fire in a lichen tussock tundra habitat, northwestern Alaska. Reported values are relative cover on the transects expressed as a percent. 


\begin{tabular}{l|l|r|r|r|r|r|r|r|r|r}
\hline & \multicolumn{2}{|c|}{1981} & \multicolumn{2}{c|}{1982} & \multicolumn{2}{c|}{1983} & \multicolumn{2}{c|}{1984} & \multicolumn{2}{c}{1995} \\
& \multicolumn{2}{|c|}{ Burn/Control } & Burn/Control & \multicolumn{1}{c|}{ Burn/Control } & \multicolumn{2}{c}{ Burn/Control } & \multicolumn{2}{c}{ Burn/Control } \\
\hline Lichen & 0.5 & 28.4 & 1.2 & 39.9 & 0.9 & 38.2 & 0.0 & 35.0 & 3.2 & 27.2 \\
Moss & 7.8 & 12.8 & 7.0 & 7.7 & 4.9 & 10.2 & 1.1 & 9.9 & 2.6 & 6.0 \\
Grass/Sedge & 0.3 & 12.6 & 16.4 & 15.6 & 27.4 & 20.0 & 34.1 & 18.0 & 53.9 & 40.2 \\
Forb & 0.0 & 5.4 & 2.8 & 5.3 & 3.0 & 4.2 & 4.0 & 5.2 & 3.5 & 3.6 \\
Shrub & 0.0 & 28.0 & 10.0 & 33.2 & 13.4 & 39.4 & 19.0 & 48.4 & 30.4 & 35.7 \\
Litter & 0.0 & 16.0 & 56.2 & 7.2 & 71.8 & 18.4 & 60.6 & 16.0 & 9.7 & 7.8 \\
Species Richness & 8 & 20 & 15 & 20 & 13 & 18 & 9 & 16 & 17 & 23 \\
Diversity (H') & & & & & & & & & 1.49 & 1.96 \\
\hline \hline
\end{tabular}

Table 2. Changes in vegetative canopy cover over time in a tussock tundra community burned in July 1981 (one week preceding the first sampling) expressed in per cent. Within quadrats, plant cover was estimated within six percentage categories and midpoints used to generate means (Daubenmire 1959).

unburned plots averaged $28 \%$ (Table 1). However, crowberry (Empetrum nigrum) appeared to be recovering much more slowly than other shrubs. The average percent cover of crowberry on unburned plots over all the study years was $5.7 \%$ (Daubenmire plots), but the average in burned transects in 1981 was $0.0 \%$ and by 1995 it had only increased to $0.2 \%$.
Lichen cover in control plots should have varied little between 1981 and 1995, but could have been subjected to grazing by caribou or disturbance by trampling. Signs of recent caribou utilization within transects were not noted during surveys. Measured lichen cover $(27.2 \%)$ using the quadrat cover class method in 1995 was similar to the 1981 estimate of $28.4 \%$

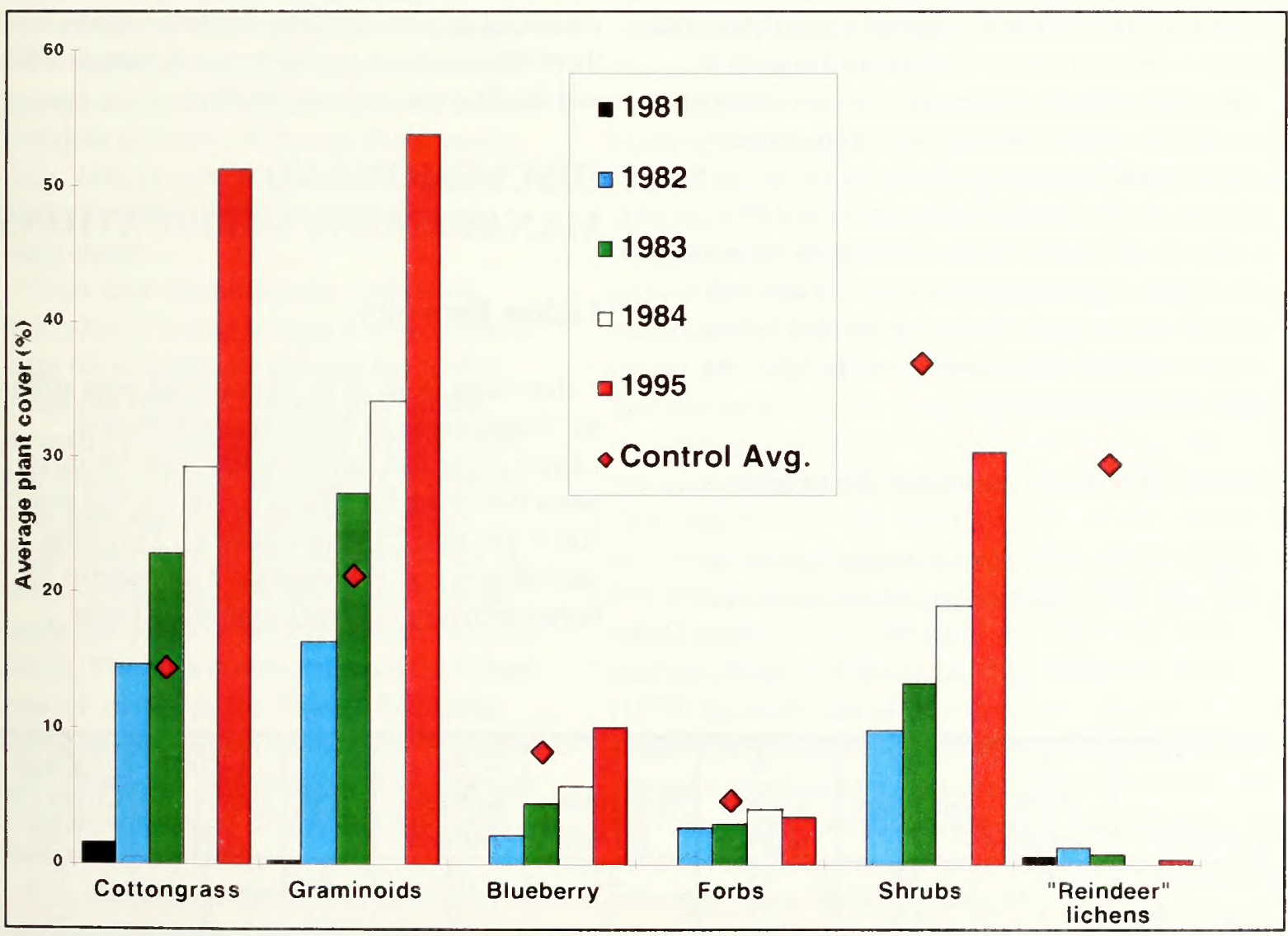

Figure 2. Plant cover over time on burn and control transects, Buckland Valley, Alaska: percent cover based on quadrat cover class estimates (Table 1). 
on control transects, indicating that data collected by two observer pairs from different years was reasonably comparable (Table 2 ). The overall composition of control plots was similar to results obtained in 1981, except for an increase in graminoid cover, primarily cottongrass, which increased by about three-fold (Fig. 2, Table 2).

Species richness was reduced by half initially, and in 1995 was still lower in the burned (17 species) transects $v s$. control ( 23 species) transects. The mean Shannon diversity index was determined using point transect data. There was less diversity in the 14-year-old burned transects $\left(\mathrm{H}^{\prime}=1.49\right)$ than the unburned controls $\left(H^{\prime}=1.96\right)$. Species found in the control plots that were not recorded in burn plots tended to be plants of small stature and low frequency such as Cladonia uncialis, Thamnolia spp.,

Oxycoccus microcarpus, and Andromeda polifolia. These tiny plants could easily escape detection if present in trace quantity.

Both Ulukluk Creek transects were light-tomoderately burned and the overall BSI (burn severity index) was equivalent for both transects (Table 3). The fact that Transect 1 had more area that was just scorched (34\%) than Transect 2 (18\% scorched or unburned) may be related to the slightly greater lichen cover percentage observed in Transect 1 in 1982 (1.7\% vs. $0.8 \%)$ and also to the greater lichen cover in 1995 (Table 3). However, these differences were not significant, and when plots were studied individually to compare burn severity and lichen cover in 1982 to the lichen cover in 1995, no clear pattern is apparent.

\section{Lichen Recovery on Older Burn Sites}

Other Buckland Valley sites that burned in 1970 and 1972 shared many characteristics of the Ulukluk Creek study, including low percentage of lichen cover, remnants of dead Labrador tea, foliose lichens in wet intertussock spaces, and early stages of most fruticose lichens still less than $1 \mathrm{~cm}$ in length. All Buckland Valley sites could have been subject to grazing or disturbance by caribou from the Western Arcrtic Herd, which increased steadily during the recovery period. To see whether the observed recovery times in the Buckland Valley were retarded by repeated caribou disturbance, paired transects were established in 1997 on two older burn sites from a Seward Peninsula region that has received very little grazing pressure by caribou or reindeer during the last 50 years. Both sites were also located in lichen tussock tundra and were similar to the Ulukluk site, except that lichens had been relatively undisturbed at these sites since the fires. At Wagon Wheel, which burned in 1977, the percent lichen cover was 4.3 \pm 0.7 compared to $49.3 \pm 1.3$ on the unburned control (Table 4). In the aftermath of a 25 -yearold fire on the Pargon River (1972), lichen cover was $3.2 \pm 0.4 \%$ compared to $40.0 \pm 1.1 \%$ for the unburned control (Table 4). Lichen recovery measured as percent of the unburned control was therefore similar at the 20-year-old burn $(8.7 \%)$ and the 25-year-old burn ( $8.0 \%)$.

\section{DISCUSSION AND MANAGEMENT IMPLICATIONS}

\section{Lichen Recovery}

Burn sites from 14 to 25 years old were still in the initial stages of lichen reestablishment. Lichen cover had increased less than $3 \%$ in 14 years following fire (Table 2, Fig. 2), and was still $<5 \%$ after 25 years (Table 4 ). This slow pace of recovery is consistent with patterns for lichen recovery in boreal coniferous forest

\begin{tabular}{l|c|c|c|c|c|c|c|c}
\hline \hline Transect & $\begin{array}{c}\% \\
\text { Area } \\
\text { Unburned }\end{array}$ & $\begin{array}{c}\% \\
\text { Scorched }\end{array}$ & $\begin{array}{c}\% \\
\text { Lightly } \\
\text { Burned }\end{array}$ & $\begin{array}{c}\% \\
\text { Moderately } \\
\text { Burned }\end{array}$ & $\begin{array}{c}\% \\
\text { Severely } \\
\text { Burned }\end{array}$ & BSI & $\begin{array}{c}\text { Lichen } \\
\text { Cover (\%) } \\
1982\end{array}$ & $\begin{array}{c}\text { Lichen } \\
\text { Cover }(\%) \\
1995\end{array}$ \\
\hline Burned \#1 & 0 & 34 & 43 & 22 & 0 & 3 & 2 & 5 \\
Burned \#2 & 4 & 15 & 75 & 6 & 0 & 3 & 1 & 2 \\
\hline \hline
\end{tabular}

Table 3. Comparison of burn severity index (BSI) and percent lichen cover by quadrat cover class after one year and 14 years at Ulukluk Creek fire recovery study site, Alaska. 
reported by Ahti (1977). Ahti found that reindeer lichens such as Cladina mitis, $C$. arbuscula, C. rangiferina and Cladonia uncialis did not become dominant until 50 120 years after fire and noted that moisture regime and climate were important factors affecting time spent in various successional stages.

Lichens establish by a variety of sexual and asexual propagules. Many fruticose lichen taxa including Cladonia, Cladina, Bryoria and Ramalina are highly adapted to propagate by thallus fragments (Dibben 1971, Nash 1996). Reestablishment of reindeer lichens such as Cladina spp. may occur by slow reinvasion of wind-blown fragments (Johnson 1981, Moreau and Payette 1989). Many types of lichen propagules are carried substantial distances when melt water flows across arctic tundra in the spring. Dispersal of lichen propagules by wind blowing over smooth snow in winter is believed to be particularly significant in local dispersal (Thompson 1972). A small burn, included within a larger unburned tussock tundra habitat providing a local source of lichen propugules, should present the best conditions for early reestablishment of lichen. Although these conditions were present at Ulukluk Creek, we found reestablishment to be in the very early stages.

Even after establishment, growth of individual Cladina lichens is slow. Growth rates for Cladina rangiferina have been measured at 5 to $6 \mathrm{~mm}$ per year on the Seward Peninsula of Alaska (Pegau 1968; and Meyers, unpublished data). However, over time and in the absence of major disturbance such as fire, heavy grazing or severe trampling, lichens on arctic rangelands can compete favorably with vascular plants. Production data gathered for lichen tussock tundra on the Seward Peninsula estimated live lichen biomass at $111.5 \mathrm{~g} / \mathrm{m}^{2}$ (995 lb/ac) and an average annual vascular plant production of $63.3 \mathrm{~g} / \mathrm{m}^{2}$ (565 lbs/ac: Swanson et al. 1985).

Fire alters the competitive relationship between lichens and vascular plants on arctic rangelands. On shallow, cold and nutrient-poor arctic soils underlain by permafrost and topped by an insulating mat of organic material, lichens exist in a reasonably competitive status with vascular plants. Lichens can utilize nutrients stored in the organic mat, whereas vascular plants grow better in mineral soil (Ahti and Hepburn 1967, Topham 1977, Lawrey 1984, Swanson et al. 1985). Many fruticose lichens are lightly entangled within the live vegetative surface layer and are readily killed by fire (Longton 1988). In contrast, many vascular plant species have roots and meristems more deeply buried in moist vegetative mats or mineral soil and are better able to withstand a tundra fire (Wein and Bliss 1973). Fire reduces or eliminates the organic mat, decreases surface albedo, promotes thaw of mineral soil and enhances availability of mineral nutrients. All of these actions directly benefit vascular plants (Viereck and Schandelmeir 1980, MacLean et al. 1983).

\section{Recovery of Vascular Plants}

A common finding by Racine (1981), Wein and Bliss (1973) and current study was the rapid postfire recovery of graminoids, especially cottongrass. All studies cited vigorous basal sprouting and significantly increased density of flowering shoots one to two years after fire.

Cottongrass cover values in the burned transects exceeded those in the unburned transects by $11 \%$ after 14 years (Table 1), and $19 \%$ after 20 years and $20 \%$ after 25 years (Table 4 ). Physiological studies (Chapin et al. 1979) have shown that the tussock growth habit of $E$. vaginatum creates a favorable microclimate that becomes snow-free sooner, with a longer growing season than between-tussock areas. Soil temperature within the tussock is raised, enhancing nutrient cycling and root growth. Chapin and associates suggest the link between the high productivity and widespread distribution of cottongrass may be a result of the tussock growth form. The competitive advantage of the tussock growth form, plus an initial pattern of warmer soils and improved plant nutrient status as demonstrated by Wein and Bliss (1973) for dominant plant community species may explain the continued dominance of cottongrass in burned tussock tundra sites over time. Carex spp. did not follow this pattern and generally had the same or lower cover values in burned plots compared to unburned plots (Table 1, Table 4).

We cannot account for the three-fold increase of graminoid cover on unburned control tran-sects in Ulukluk Creek in 1995 (40\%) compared to 1984 


\begin{tabular}{l|r|r|r|r|r|r|r|r|r|r}
\hline \multirow{2}{*}{ Cover Type } & \multicolumn{3}{|c|}{ Wagon Wheel 1977 Burn } & \multicolumn{3}{c}{ Pargon River 1972 Burn } \\
\cline { 2 - 9 } & Unburned & SE & Burned & SE & Diff. & Unburned & SE & Burned & SE & Diff. \\
\hline Carex spp. & 5.5 & 1.5 & 1.5 & 0.9 & -4.0 & 7.2 & 1.9 & 7.7 & 1.5 & +0.5 \\
Eriophorum spp. & 13.3 & 3.0 & 32.7 & 3.7 & +19.3 & 10.5 & 2.1 & 30.0 & 3.2 & +19.5 \\
Other graminoid & 0.0 & - & 0.0 & - & 0.0 & 0.0 & - & 0.2 & - & +0.2 \\
Total Graminoid: & 18.8 & 2.9 & 34.2 & 3.8 & +15.3 & 17.7 & 2.7 & 37.8 & 2.9 & +20.2 \\
Rubus chamaemorus & 1.2 & 0.5 & 4.8 & 1.2 & +3.7 & 1.8 & 0.5 & 4.0 & 1.1 & +2.2 \\
Other forb & 1.2 & - & 0.0 & - & -1.2 & 0.0 & - & 0.0 & - & 0.0 \\
Total Forb: & 2.3 & 0.7 & 4.8 & 1.2 & +2.5 & 1.8 & 0.5 & 4.0 & 1.1 & +2.2 \\
Ledum palustre & 3.8 & 0.8 & 23.0 & 2.6 & +19.2 & 6.0 & 0.7 & 9.0 & 1.9 & +3.0 \\
Vaccinium uliginosum & 5.0 & 1.1 & 5.3 & 1.8 & +0.3 & 13.7 & 1.4 & 15.3 & 3.6 & +1.7 \\
Betula nana & 1.8 & 0.6 & 2.7 & 1.3 & +0.8 & 1.8 & 0.7 & 1.3 & 0.9 & -0.5 \\
Empetrum nigrum & 2.5 & 1.0 & 0.0 & 0.0 & -2.5 & 2.3 & 1.6 & 0.0 & 0.0 & -2.3 \\
Other shrub & 2.2 & - & 3.8 & - & +1.7 & 9.0 & - & 13.0 & - & +4.7 \\
Total Shrub: & 15.3 & 1.6 & 34.8 & 2.8 & +19.5 & 32.3 & 2.3 & 38.8 & 2.6 & +6.5 \\
Cladonia rangiferina & 25.3 & 2.4 & 0.7 & 0.4 & -24.7 & 15.2 & 1.8 & 0.5 & 0.4 & -14.7 \\
C. mitis/arbuscula & 8.8 & 1.4 & 0.8 & 0.4 & -8.0 & 17.0 & 2.6 & 1.5 & 0.7 & -15.5 \\
Cetraria cucullata & 7.2 & 1.6 & 0.0 & 0.0 & -7.2 & 1.0 & 0.4 & 0.0 & 0.0 & -1.0 \\
C. islandica & 4.5 & 0.8 & 0.0 & 0.0 & -4.5 & 5.0 & 0.8 & 0.2 & 0.2 & -4.8 \\
Other lichen & 3.5 & - & 2.8 & - & -0.7 & 2 & - & 1.0 & - & -1.0 \\
Total Lichen: & 49.3 & 4.4 & 4.3 & 2.3 & -45.0 & 40.0 & 3.8 & 3.2 & 1.2 & -36.8 \\
\hline \hline
\end{tabular}

Table 4. Comparison of paired control and burned transects at two sites 20-25 years after fire in a lichen tussock tundra habitat, northwestern Alaska (results in percent canopy cover based on point-intercept sampling).

(18\%) (Table 2). If the original investigators counted only the basal area of tussock-forming graminoid species, whereas we estimated the canopy cover, this might have caused the disparity. However, we cannot rule out a real increase in graminoid cover on the control plots, due to seed saturation from the nearby burn, effects of caribou disturbance, or other environmental factors. Graminoid cover is consistently greater on the burned plots from the third season post-burn.

Dwarf shrubs increased steadily over time on burned plots (Fig. 2) and shrub cover had recovered to approximate pre-burn levels after 14 years (Table 2 ). The trend in shrub cover increase on burned plots is still evident after 20 and 25 years. Cover values for shrubs appeared to peak after 20 years on Wagon Wheel burned plots, $35 \%$ compared to $15 \%$ on the unburned. By 25 years following fire, Pargon River burned plots showed $39 \%$ shrub cover, with $32 \%$ shrub cover in unburned plots (Table 1). Dwarf shrub recovery at all three transect sites was largely due to a positive cover increase by Labrador tea (Table 1, Table 4). Of the four most common shrub species present, only crowberry failed to recover at least $70 \%$ of its former cover values 14 years after fire. At Ulukluk Creek 14 years post-fire, crowberry cover was $0.9 \%$ compared to $2.9 \%$ cover in the unburned transects (Table 1). At Wagon Wheel and Pargon River, crowberry was not documented in the burned plots, although it did contribute low cover values of $2.5 \%$ and $2.3 \%$ in the unburned transects (Table 4). This differential recovery may be related to the depth or location of underground stems and 
roots that are the sites of resprouting after fire. Dwarf shrubs that grow deeply into the organic mat or tussock mass might incur less fire damage and re-establish more quickly than those near the surface. Crowberry has shallow roots and a complex of horizontal stems thinly buried in the organic mat, resulting in a below-ground biomass located near the surface (Shaver and Cutler 1979). In contrast, Labrador tea had roots at intermediate depths (Shaver and Cutler 1979). Racine (1981) found no crowberry in sedge tussock-shrub tundra on the Seward Peninsula two years after fire, while other dwarf shrubs, such as Labrador tea, lowbush cranberry (Vaccinium vitis-idaea) and blueberry ( $V$. uliginosum), did show small increases in cover and stem density two years after fire.

Our study classified cloudberry (Rubus chamaemorus) as herbaceous, following Hultén (1968) and Porsild and Cody (1980), although this species is also recognized as a creeping shrub (Racine 1981, Shaver and Cutler 1979) due to its semi-woody stem base. Forbs in general comprised a small cover component (2$6 \%$ ) on all transects. Cloudberry had essentially returned to prefire cover values after 14 years (Table 1), and was two to four times higher in the burned transects 20 and 25 years after fire (Table 4).

\section{Comparison of Point-frame and Canopy Cover Class Methods}

Sampling time required for the point-intercept technique was approximately $50 \%$ of time required for the quadrat cover class (Daubenmire) method. Although half as many quadrats were deployed per transect with point-interception, the area actually sampled was $6 \mathrm{~m}^{2} \mathrm{com}-$ pared to $2.5 \mathrm{~m}^{2}$. Generally, a larger plot area reduces between-plot variance, improving the confidence of estimates.

Cover values from each of the major species appeared similar with each method, although the point-intercept method yielded slightly lower means. The average difference between percent cover values obtained with quadrat cover class method and those obtained with point-intercept was less than $4 \%$. The greatest difference between the two methods was in the estimation of lichen cover. Average lichen cover over burned transects was $3.2 \%$ by quadrat cover class estimation and $1.2 \%$ by point-intercept, while on unburned control transects we measured $27.2 \%$ and $15.4 \%$ respectively (Table 2 , Table 1). Floyd and Anderson (1987) found that quadrat class estimation overestimated small understory plants and rare species, due to the assumption that cover values are uniformly distributed about the mid-points of the cover classes; that is, a trace of lichen would be counted as $2.5 \%$. This appears to be the case for lichens in the present study, and we believe the point-intercept estimates to be better estimates of these classes and more repeatable among different observers. As previously mentioned, we believe an unexplained increase in graminoid cover on unburned control plots may be due to sampling technique by different observers using the quadrat cover class method. Since the pointintercept sampling also yielded the most conservative difference between lichen cover in burned and unburned transects, we have reported the point-intercept findings in Table 1 and used them as the basis for our conclusions.

Estimates of cover were based on first hits at the point of interception, without attempting to sample successive layers of vegetation. This can create problems when the vegetation of interest is low-growing and covered by taller plants, such as lichen growing under a dwarf shrub overstory. For future sampling, we plan to use all successive species encountered in the sighting line for estimating cover.

\section{CONCLUSION}

Tussock tundra forms the core of the Western Arctic Caribou Herd's winter range and is an important component of the herd's summer range as well. This study and other investigations of tussock tundra recovery after fire in Alaska and Canada (Racine 1981, Wein and Bliss 1973) demonstrate the resilience of tussock-forming graminoids and shrubs, and the vulnerability of lichens and mosses to wildfire. Fourteen years is early in terms of reported lichen succession, and at Ulukluk Creek both crustose and fruticose lichen species were just barely measurable in terms of cover. If the measured rate of increase is extrapolated linearly to 50 years, lichen cover would still be about $7 \%$, substantially less than the control cover of $15 \%$ and probably not enough to be valuable 
winter forage for caribou. Instead, percent lichen cover at this site is expected to increase along a non-linear curve, most likely approaching a sigmoid growth pattern over 100-200 years. Canadian observers reported significant increases in reindeer lichen biomass between stand age classes of 21-40 years and 41-60 years, and significant increases in indices of caribou use from age class 41-60 to 61-80 years (Thomas et al. 1996). Scotter (1967) previously concluded that caribou made little use of stands younger than 50 years in upland lichen forests of subarctic Canada. On the Porcupine caribou herd's winter range in Yukon Territory, Russell et al. (1993) noted that biomass of Cladonia spp. peaked between 51-125 years while that of Cetraria spp. increased with age of the stand. Amounts of reindeer lichen at our burn study sites aged 14-25 years were all below thresholds considered useful as caribou forage. Because reestablishment times vary so dramatically in different geographic locations, it is very important to continue monitoring the Buckland Valley study site at 5 -year intervals so the recovery time for this site can be accurately estimated. Other variables that may affect lichen reestablishment following fire include burn severity, precipitation, grazing pressure, trampling, fire return and soil type (Swanson et al. 1985).

Long-term monitoring of the Ulukluk Creek study site and other fire locations should be continued to obtain data for estimating timelines. The point-intercept sighting frame is an efficient and repeatable way to conduct future measurements. This study illustrates a need for an inventory of the present caribou winter range and its status relative to past fire occurrence. Fire management goals that reflect the present size and needs of the caribou herd and its users should be established, based on knowledge of ecosystem components and how much oldgrowth lichen range is available for caribou.

The area used by caribou for winter range should be managed for long fire-return intervals, with the interval determined by the recovery time of preferred forage species in this locality. At times it will be prudent to suppress wildfires in specific portions of the range, such as when the threat of very large fires is great and the supply of alternative winter range is limited.
Since knowledge of the relative importance of different habitats used by caribou throughout the year is limited, habitat use and availability studies are needed to document the importance of different seasonal habitats used by caribou and the role fire plays in these ecosystems. Although it seems clear that fire has a short-term detrimental effect on caribou winter ranges, the long-term effects ( $>50-70$ years) must also be considered. Lichen declines in productivity and quality in very old stands ( $>200$ years) and it has been reported that low-intensity fires stimulate regrowth (Klein 1982). In lichen woodlands near Abitau Lake, Northwest Territories, forest canopies began to close about 130 years postfire, with moss starting to replace the lichen component (Maikawa and Kershaw 1976). Thus, fire may play an important role in maintaining caribou winter range, especially near treeline. 


\section{LITERATURE CITED}

Adams, L.G. and B.A. Connery. 1983. Buckland River reindeer/caribou conflict study final report. USDI BLM Open File Report 8. Fairbanks, Alaska.

Ahti, T. 1977. Lichens of the boreal coniferous zone. In: Seaward, M.R.D., (ed.) Lichen ecology. N. Y.: Academic Press. 145-181.

Ahti, T. and R.L. Hepburn. 1967. Preliminary studies of woodland caribou range, especially on lichen stands in Ontario. Ontario Dept. of Lands and Forests, Resource Branch Resource Report (Wildl.) No. 74. Ottawa, Ontario.

Bergeruder, A.T. 1974. Decline of caribou in North America following settlement. J. Wildl. Manage. 38(4):757-770.

Beverly and Qamanirjuaq Caribou Management Board. 1994. Fire management on the forested range of the Beverly and Qamanirjuaq caribou herds: a technical report. The Secretariat. Ottawa, Ontario.

Black, R.A. and R.C. Bliss. 1978. Recovery sequence of Picea mariana-Vaccinium uliginosum forests after burning near lnuvik, Northwest Territories, Canada. Can. J. Botany 56:2020-2030.

BLM. 1983. Buckland Valley master habitat management plan. USDI BLM, Fairbanks, Alaska. 59pp.

Chapin, F.S., K. Van Cleve and M.C. Chapin. 1979. Soil temperature and nutrient cycling in the tussock growth form of Eriophorum vaginatum. J. of Ecology 67:169-189.

Daubenmire, R.F. 1959. A canopy coverage method of vegetation analysis. Northwest Science 33:43-64.

Davis, J.S. and P. Valkenburg. 1978. Western arctic caribou herd studies. Alaska Dept. of Fish and Game P-R Reptorts W-17-8-R and W-17-9-R. Juneau, Alaska.

Dibben, M.J. 1971. Whole-lichen culture in a phytotron. Lichenologist 5:1-10.

Floyd, D.A. and J.E. Anderson. 1987. A comparison of three methods for estimating plant cover. J. of Ecology 75:221-228.

Hultén, E. 1968. Flora of Alaska and neighboring territories. Stanford Univ. Press, Stanford, Conn.
Johnson, E.A. 1981. Vegetation organization and dynamics of lichen woodland communities in the Northwest Territories, Canada. Ecology 62(1):200-215.

Klein, D.R. 1982. Fire, lichens, and caribou. J. Range Manage. 35:390-395.

Lawrey, J.D. 1984. Biology of lichenized fungi. Praeger Press, N.Y.

Longton, R.E. 1988. Biology of polar bryophytes and lichens. Cambridge Univ. Press, N.Y.

Ludwig, J.A. and J.F. Reynolds. 1988. Statistical ecology. Wiley-Interscience, N.Y.

Machida, S. and J. Dau. 1995. Caribou. In: M.V. Hicks (ed.) Annual report of surveyinventory activities. Alaska Dept. of Fish and Game, Fed. Aid in Wildl. Restoration Project W-24-2 and 24-3, Study 3.0. Juneau, Alaska.

MacLean, D.A.; S.J. Woodle and M.G. Weber. 1983. Fire and nutrient cycling, p. 11-132. In: Wein, R.W., and D.A. MacLean (eds.) The role of fire in northern circumpolar ecosystems. John Wiley and Sons, Ltd. Chichester, England.

Maikawa, E. and K.A. Kershaw. 1976. Studies on lichen-dominated systems: XIX; the postfire recovery sequence of black sprucelichen woodland in the Abitau Lake region, Northwest Territories. Can. J. of Botany 54:2679-2689.

Miller, D.R. 1976. Wildfire and caribou on the taiga ecosystem of north-central Canada. PhD Thesis. Univ. of Idaho, Moscow, Idaho.

Moreau, C. and S. Payette. 1989. Post-fire lichen-spruce woodland recovery at the limit of boreal forest in northern Quebec. Can. J. of Botany 67:2770-2782.

Nash, T.H. (ed.) 1996. Lichen biology. Cambridge Univ, Press, N.Y.

Norberg, H.; V. Maijala, and M. Nienimen. 1995. Forage preference of semi-domestic reindeer in northern Finland. Poster presentation at Second Int. Arctic Ungulate Conf. held Aug. 13-17, 1995 (Fairbanks, Alaska)

Pegau, R.E. 1968. Growth rates of important reindeer forage lichens on the Seward Peninsula, Alaska. Arctic 21:255-259. 
Pegau, R.E. 1975. Analysis of the Nelchina caribou range, p. 316-323 In: Luick, J.R.; P.C. Lent, D.R. Klein and R.G. White, (eds.) Proc. of First Int. Reindeer and Caribou Symposium, Aug. 9-11, 1972 (Fairbanks, Alaska). Biol. Papers of the Univ. of Alaska. Fairbanks, Alaska.

Porsild, A.E. and W.J. Cody. 1980. Vascular plants of continental Northwest Territories, Canada. Nat. Museums of Canada. Ottawa, Ontario.

Racine, C.H. 1981. Tundra fire effects on soils and three plant communities along a hillslope gradient in the Seward Peninsula, Alaska. Arctic (34):71-84.

Rowe, J.S.; J.L. Bergsteinsson, F.A. Padbury and R. Hermesh. 1974. Fire studies in the Mackenzie Valley. Indian and Natur. Affairs Canada Pub. QS-1567-000-EE-A1. Ottawa, Ontario, Canada.

Russell, D.E.; A.M. Martell and W.A.C. Nixon. 1993. Range ecology of the Porcupine caribou herd in Canada. Rangifer Spec. Issue 8.

Scotter, G.W. 1967. Effects of fire on barrenground caribou and their forest habitat in northern Canada. Trans. North Amer. Wildl. Conf. 32:243-254.

Scotter, G.W. 1970. Wildfires in relation to the habitat of barren-ground caribou in the taiga of northern Canada: Proc. Tall Timbers Fire Ecol. Conf. (Tallahassee, Florida). 10:85-106.

Shaver, G.R. and J.C. Cutler. 1979. The vertical distribution of live vascular phytomass in cottongrass tussock tundra. Arctic and Alpine Res. 11:335-342.

Swanson, D.K. 1996. Fruticose lichen distribution in the Kobuk Preserve Unit, Gates of the Arctic National Park. USDI NPS Tech. Rept. AFA RNR/NRTR-96/28. Anchorage, Alaska.

Swanson, J.D.; M. Schuman and P.C. Scorup. 1985. Range survey of the Seward Peninsula reindeer ranges, Alaska. USDA Soil Conserv. Service. Anchorage, Alaska.

Thomas, D.C.; S.J. Barry and G. Alaie. 1996. Fire-caribou-winter range relationships in northern Canada. Rangifer 16(2):57-67.
Thomson, J.W. 1972. Distribution patterns of American arctic lichens. Can. J. Botany 50:1135-1156.

Thomson, J.W. 1984. American arctic lichens: 1. The macrolichens. Columbia Univ. Press, N.Y.

Topham, P.B. 1977. Colonization, growth, succession and competition, p. 31-68. In: Seaward, M.R.D. (ed.) Lichen ecology. Academic Press, N.Y.

Viereck, L.A.; M.J. Foote, C.T. Dyrness, K. Van Cleve, D. Kane and R. Siefert. 1979.

Preliminary results of experimental fires in the black spruce type of interior Alaska. USDA Forest Service Resource Note PNW332. Portland, Ore.

Viereck, L.A. and L.A. Schandelmeier. 1980. Effects of fire in Alaska and adjacent Canada - a literature review. USDI BLM. Tech. Rept. 6. Anchorage, Alaska.

Wein, R.W. and L.C. Bliss. 1973. Changes in arctic Eriophorum tussock communities following fire. Ecology 54(4):845-852. 


\section{Appendix A: Tundra fire recovery at Ulukluk Creek study site}

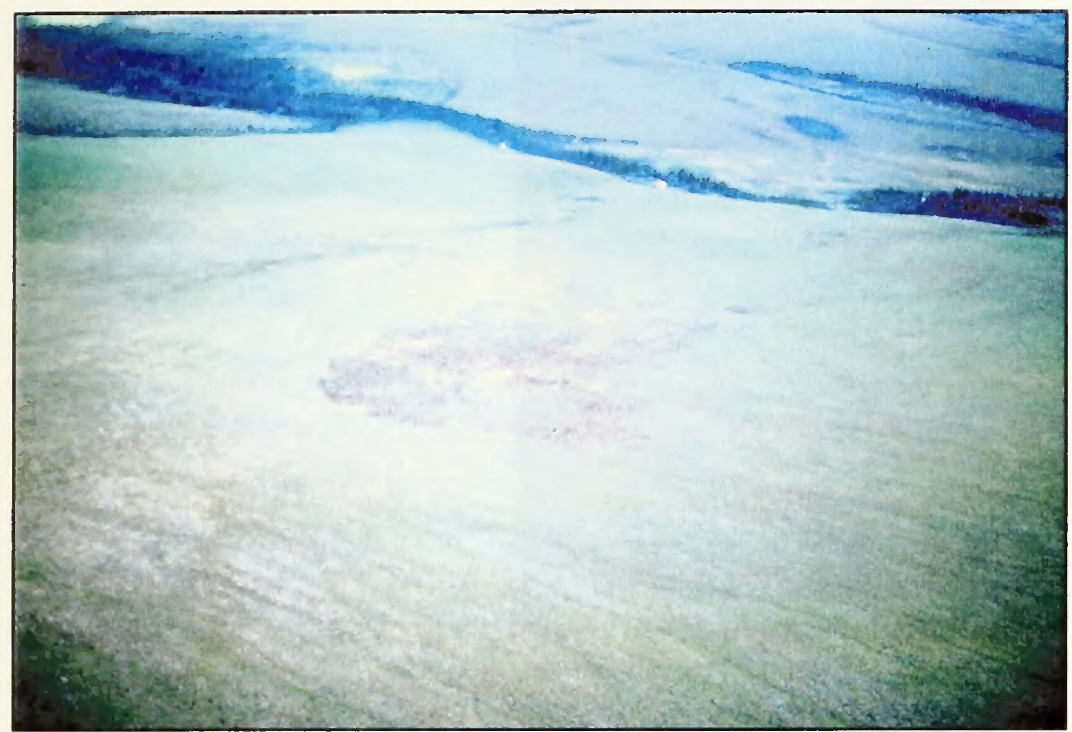

A-1. General aerial view of 2 ha burn scar in 1983, two years post-burn

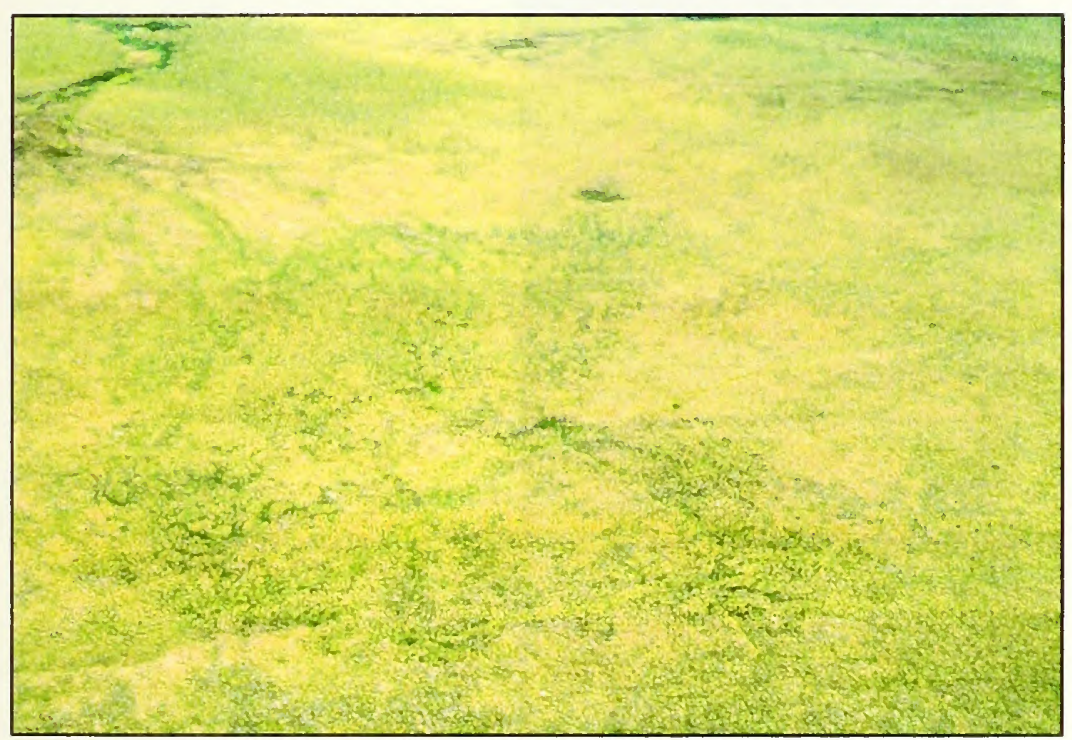

A-2. Aerial view of the burn scar in 1995. Although more difficult to discern, the burn appears slightly darker than surrounding vegetation, probably due to lack of light-colored lichen. The point of origin is still clearly visible as a dark spot (wet depression) at the top of the photo. 
Appendix B: Transect one (T1) and transect two (T2) at one month, one year, and 14 years post-burn

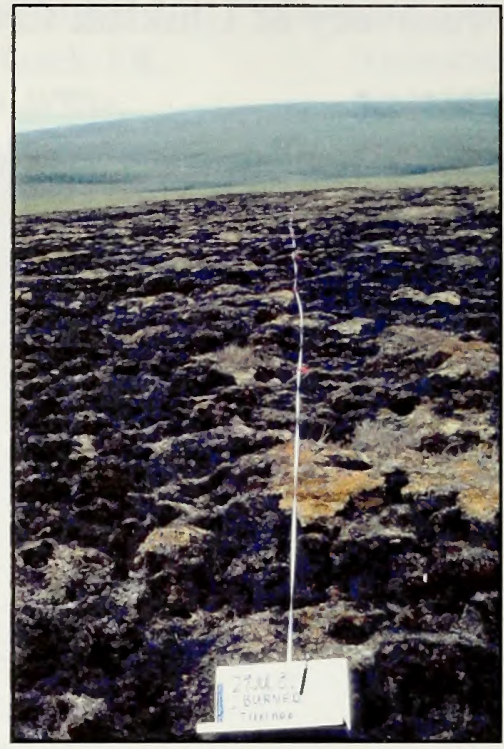

B-1. T1-Burned, July 1981, from origin.

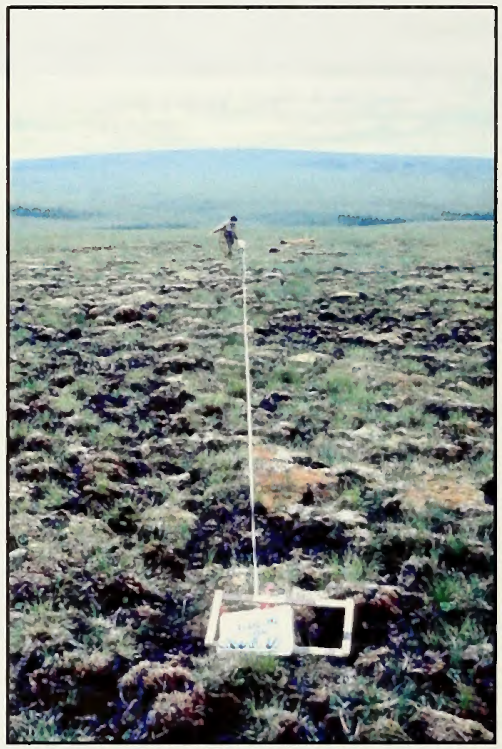

B-2. T1-Burned, July 1982, from origin.

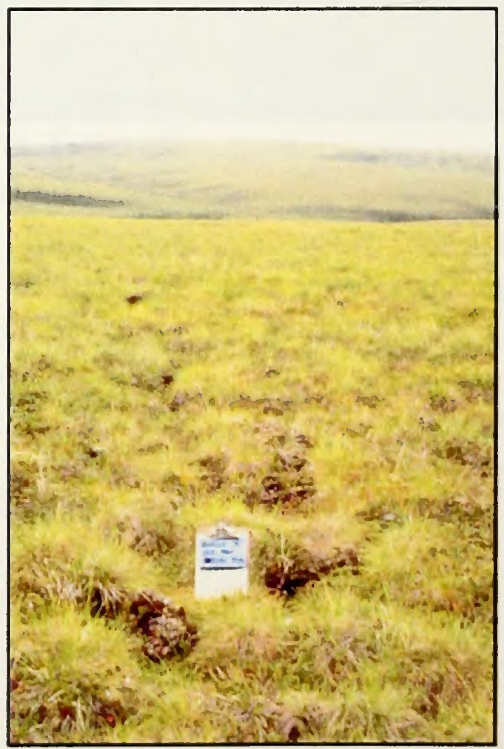

B-3. T1-Burned, August 1995, from origin. 
Appendix B (continued)

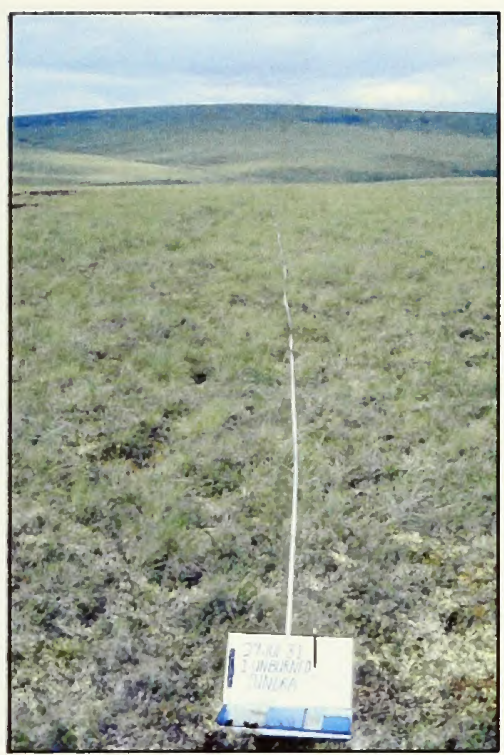

B-4. T1-Control, July 1981, from origin.

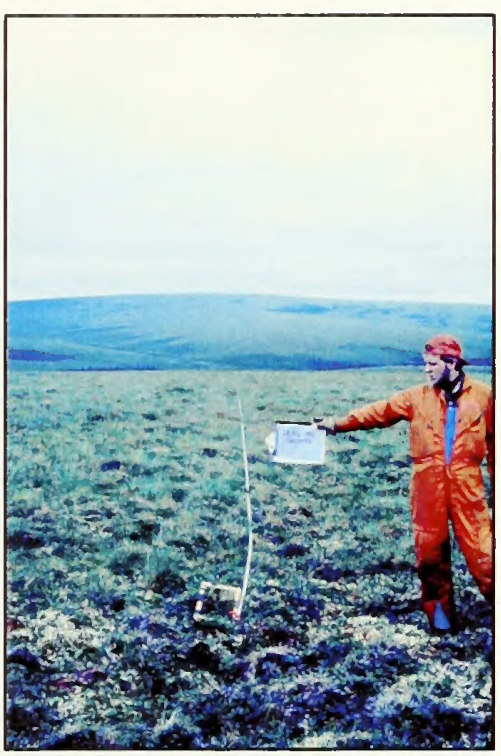

B-5. T1-Control, July 1982, from origin

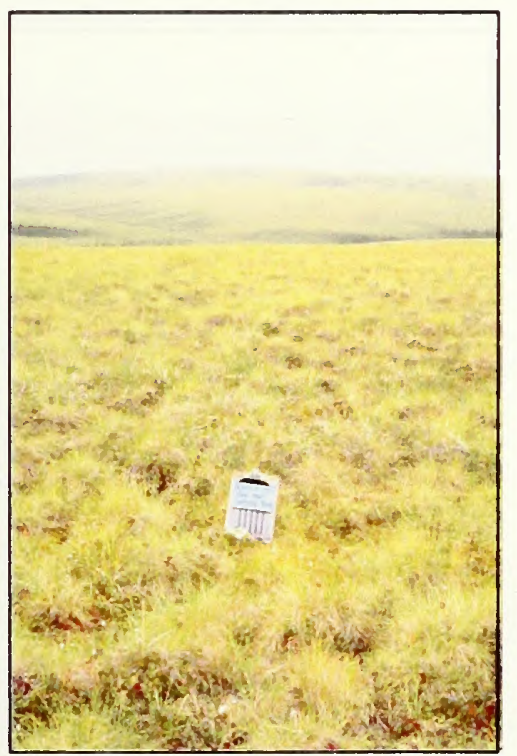

B-6. T1-Control, August 1995, from origin. 


\section{Appendix B (continued)}

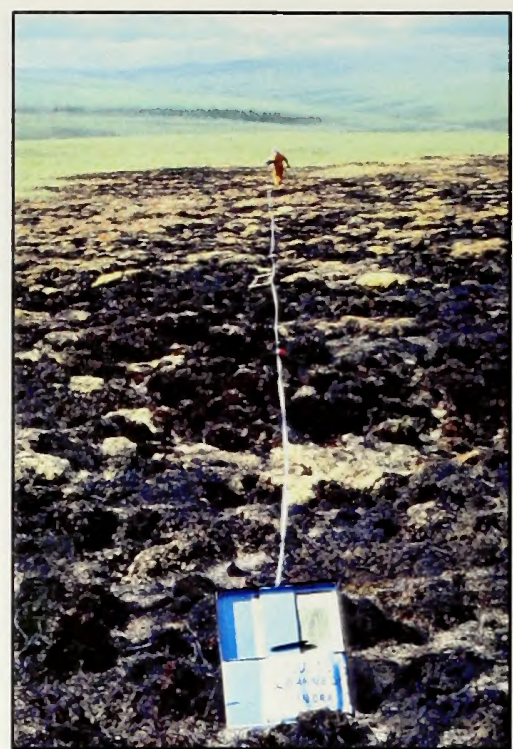

B-7. T2-Burned, July 1981, from origin.

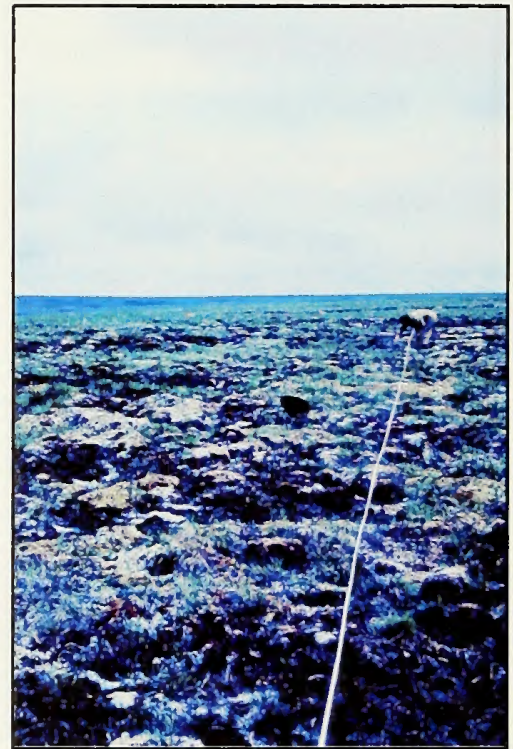

B-8. T2-Burned, July 1982, from origin.

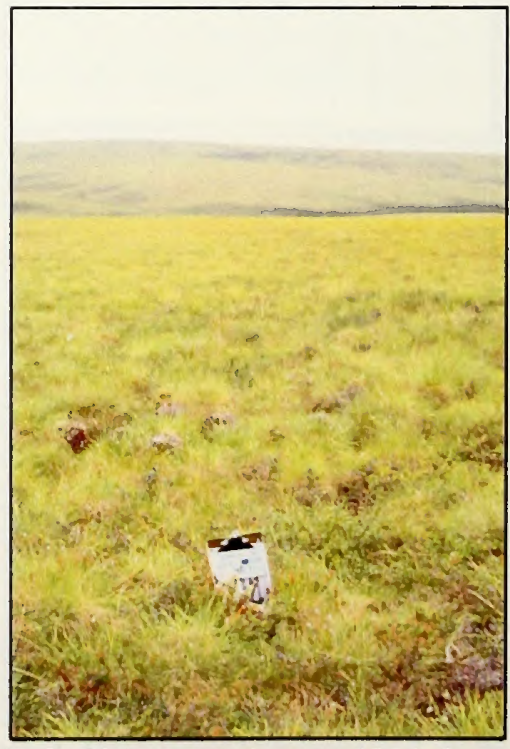

B-9. T2-Burned, August 1995, from origin. 
Appendix B (continued)

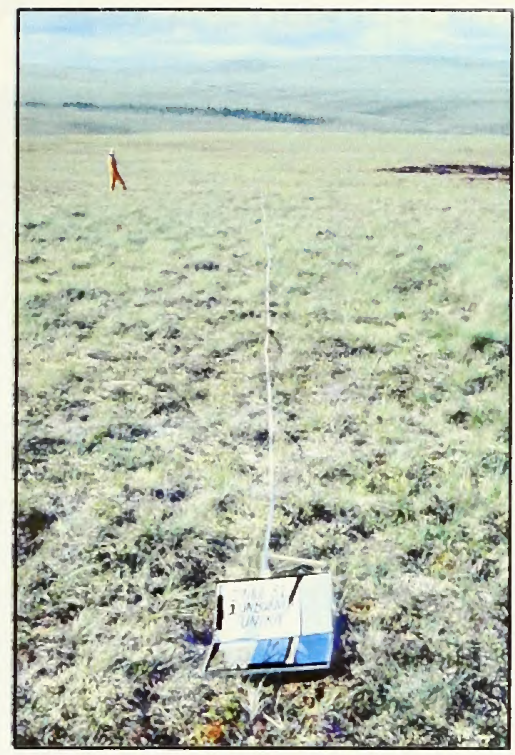

B-10. T2-Control, July 1981, from origin

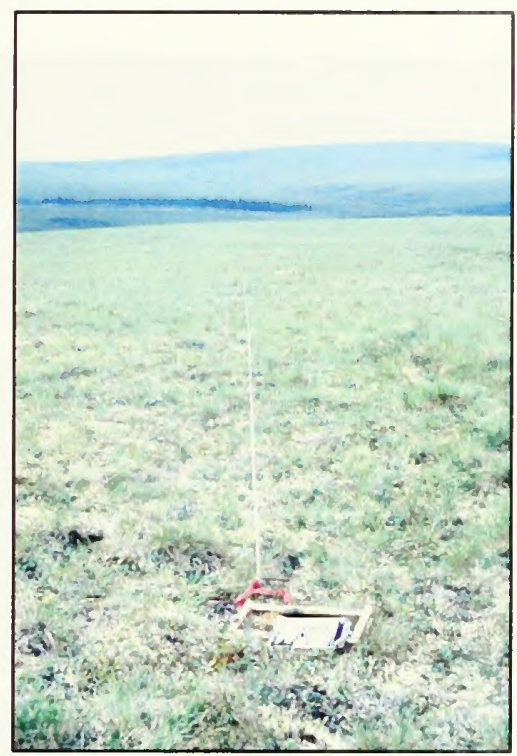

B-11. T2-Control, July 1982, from origin

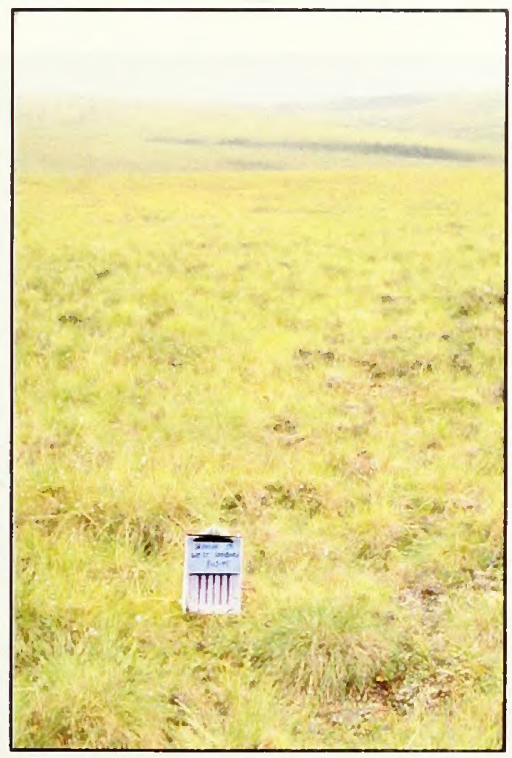

B-12. T2-Control, August 1995, from origin 


\section{Appendix C: Three-year photoplot comparison.}

Plots located at the burn edge and marked with metal stakes. Following are two of six photoplots studied.

C-1. Photoplot 2A,

7 August 1981

C-2. Photoplot 2A,

17 July 1982 .
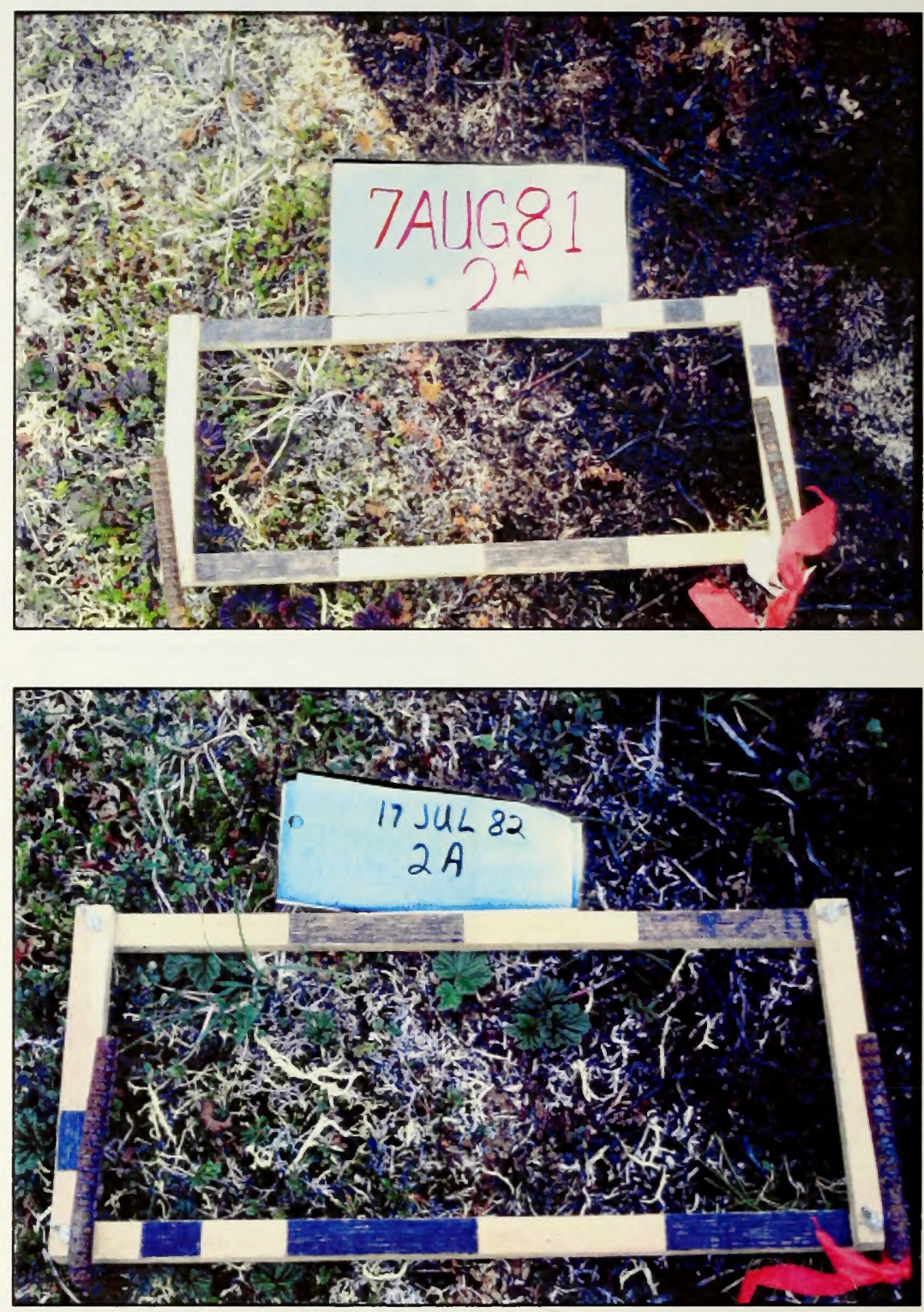

C-3. Photoplot 2A,

4 July 1983.

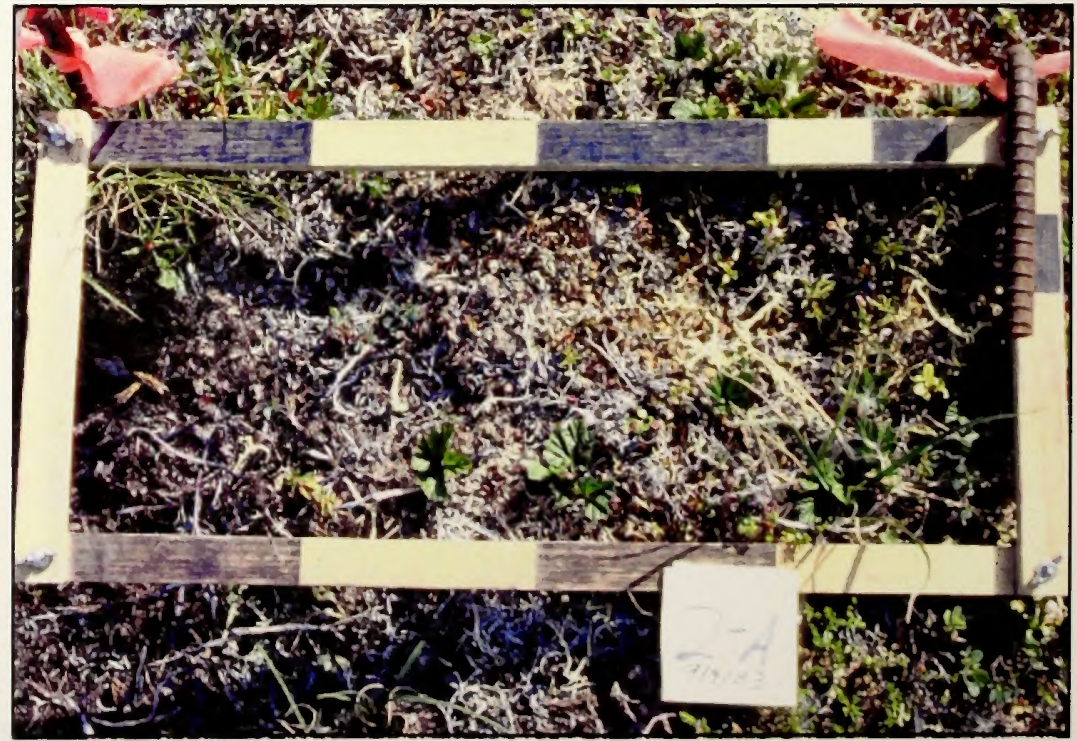



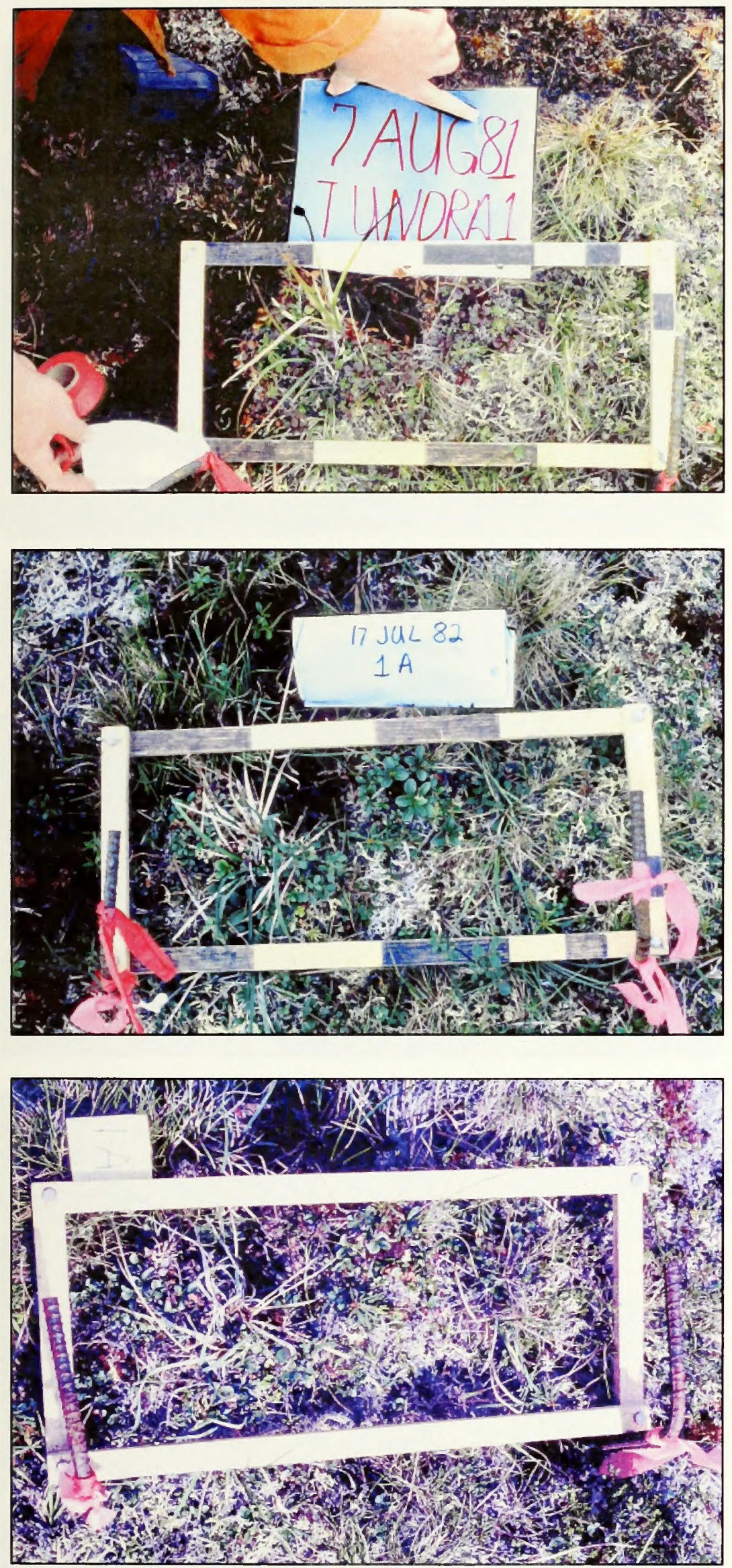

C-4. Photoplot 1A,

7 August 1981

C-5. Photoplot 1A,

17 July 1982

C-6. Photoplot 1A,

4 July 1983 
Appendix D: Successional changes on individual quadrats at one month, two years, and 14 years following fire at the Ulukluk Creek study site.

D-1. Burned T2-20m, 1981

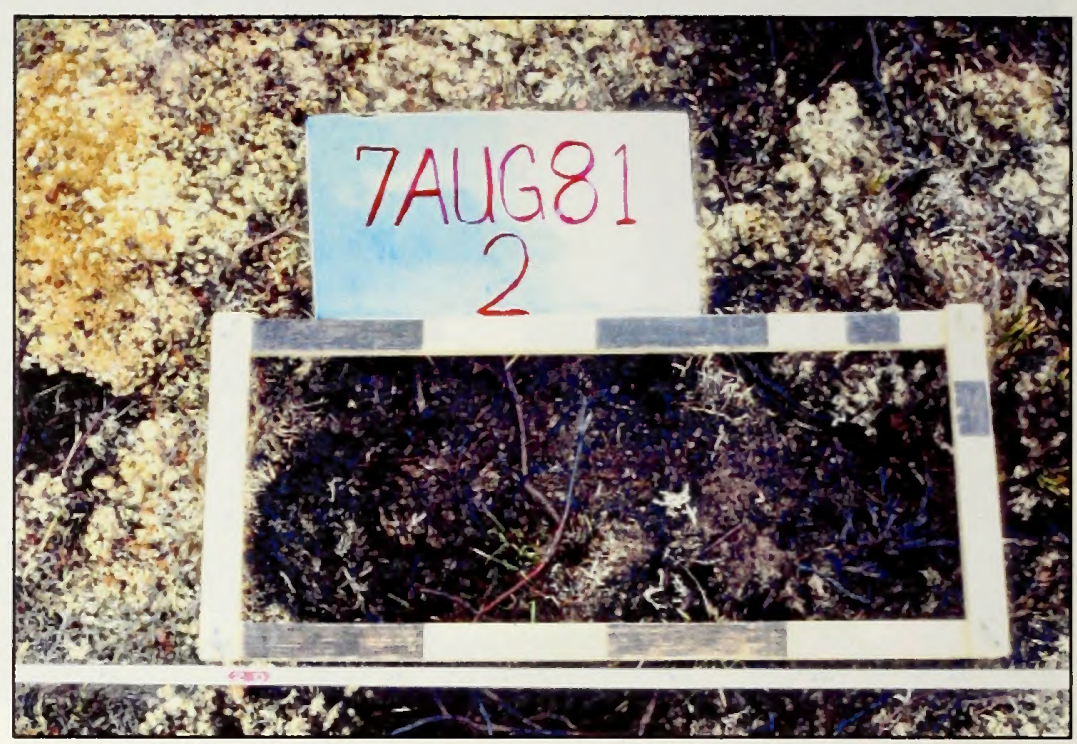

D-2. Burned T2-20m, 1983

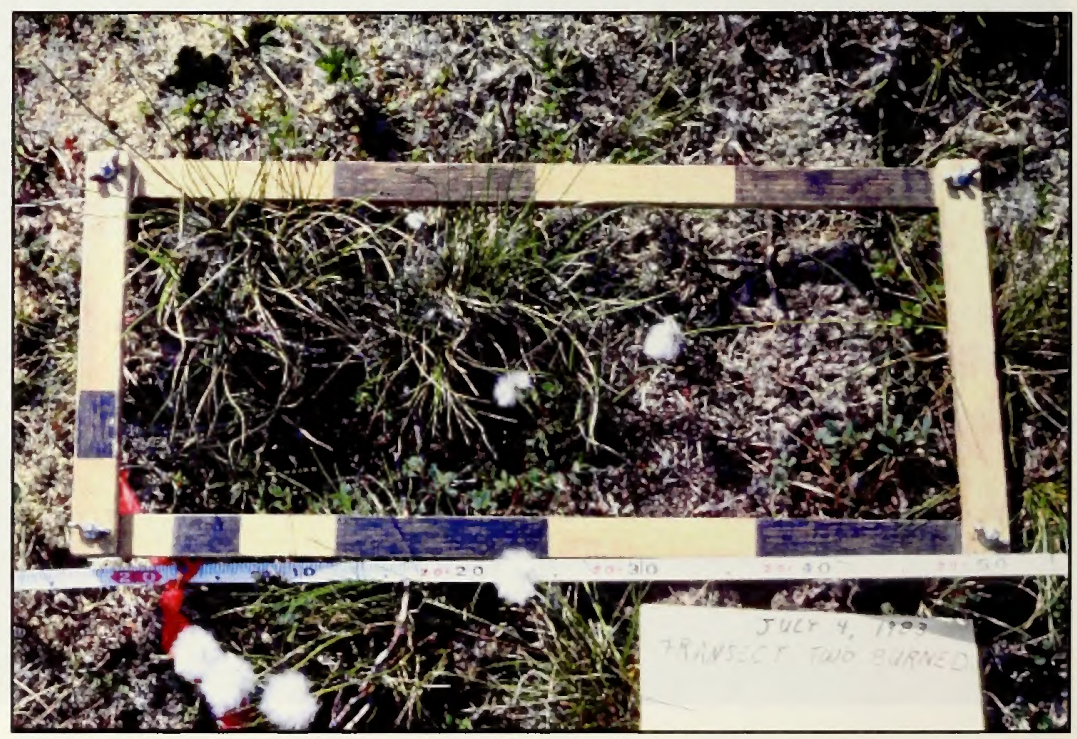

D-3. Burned T2-20m, 1995

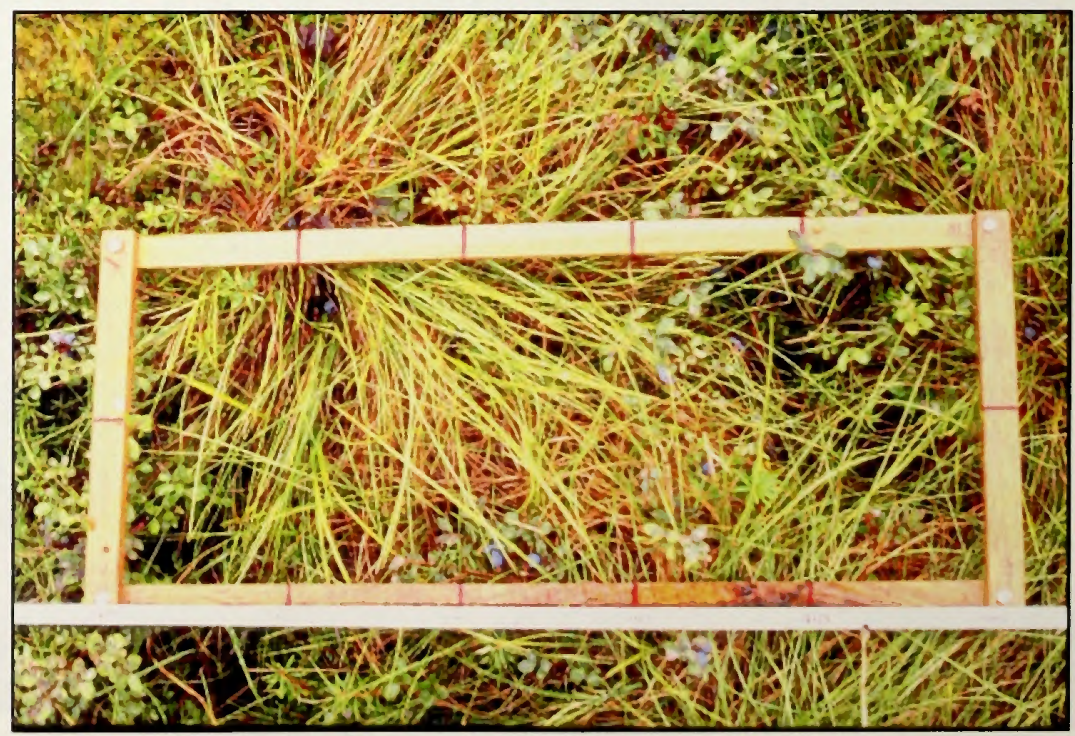



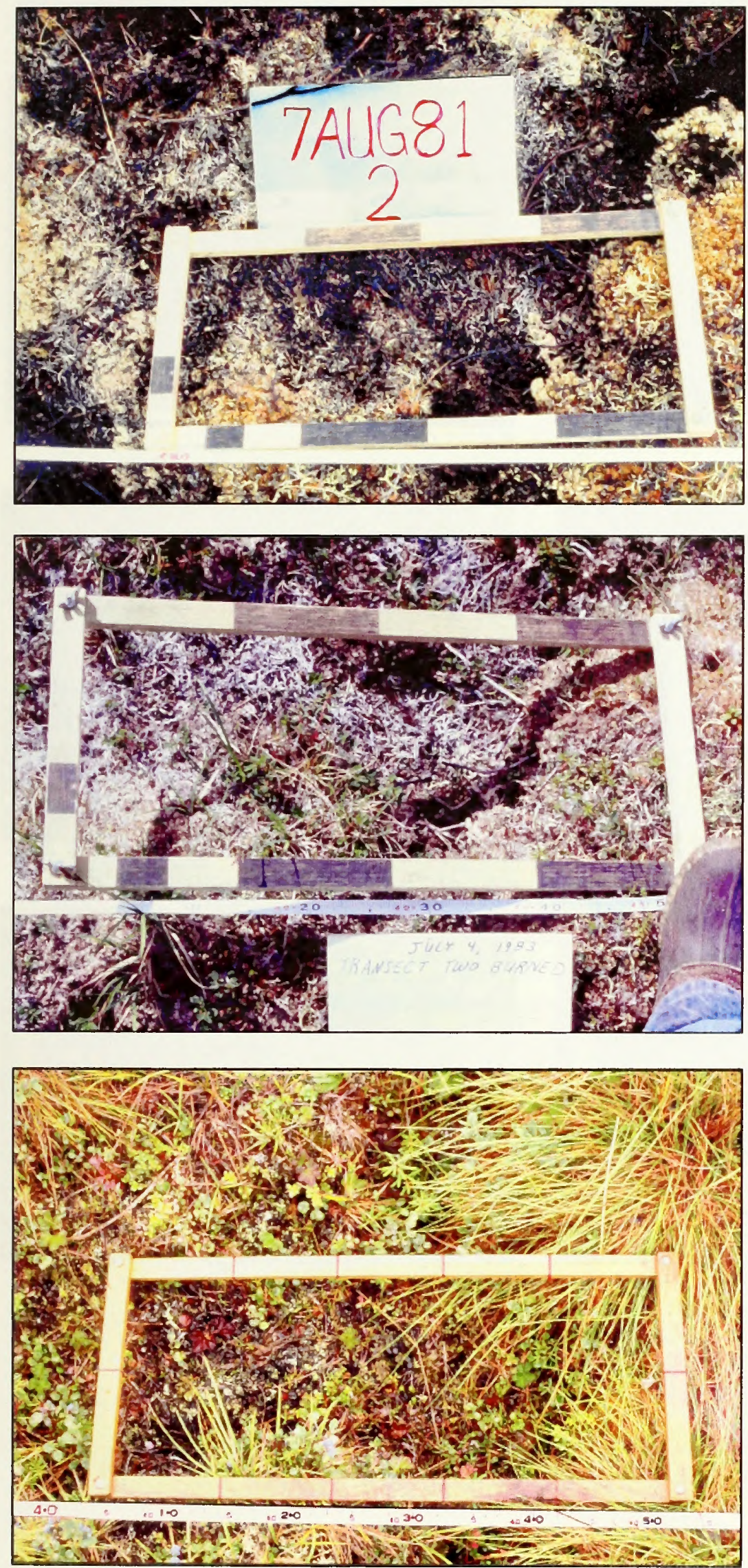

D-4. Burned T2-40m, 1981

D-5. Burned T2-40m, 1983

D-6. Burned T2-40m, 1995 
Appendix E: Comparison of individual unburned control quadrats at the Ulukluk Creek study site from 1983-1995. Little change is evident.

1983

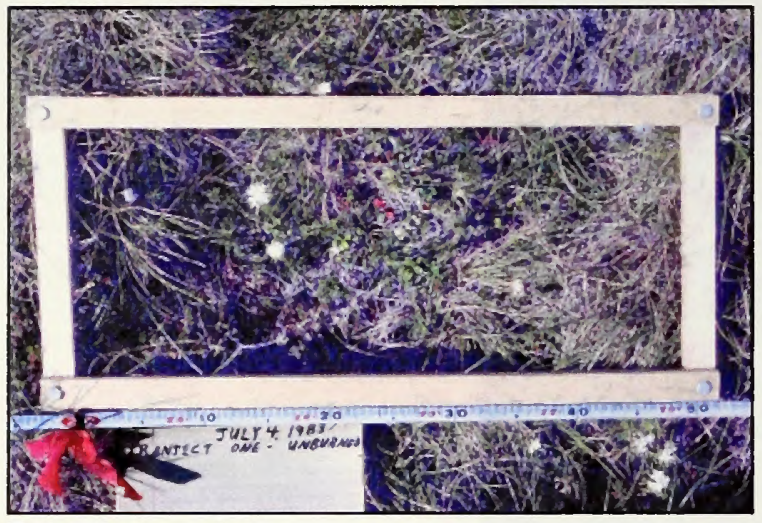

E-1. T1 Control-20m

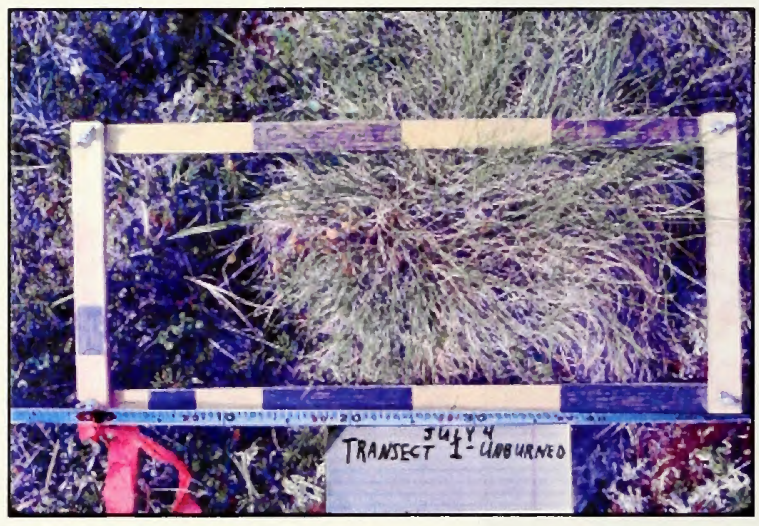

E-2. T1 Control-30m

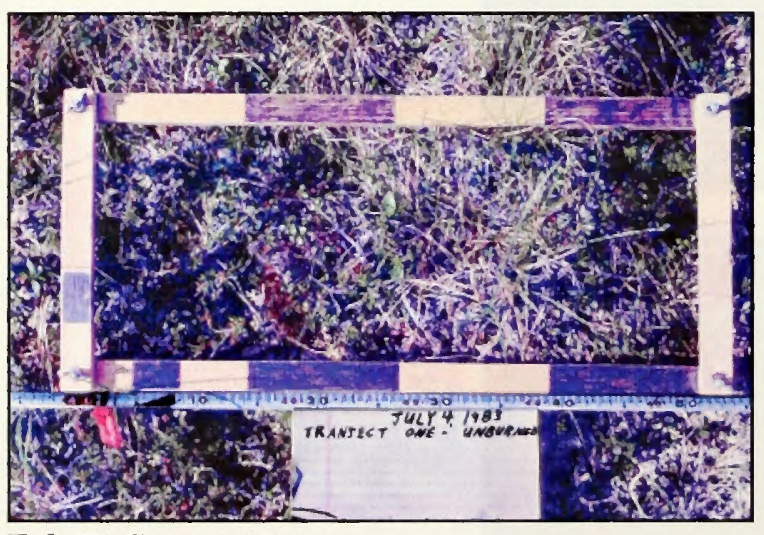

E-3. T1 Control-40m
1995

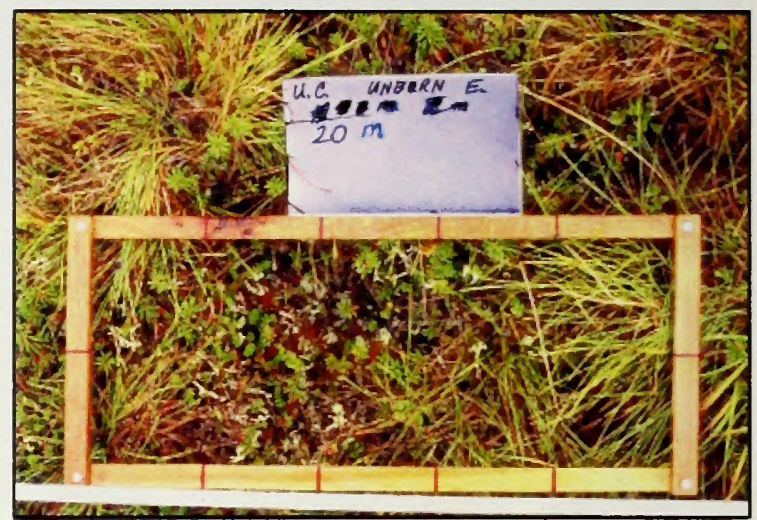

E-4. T1 Control-20m

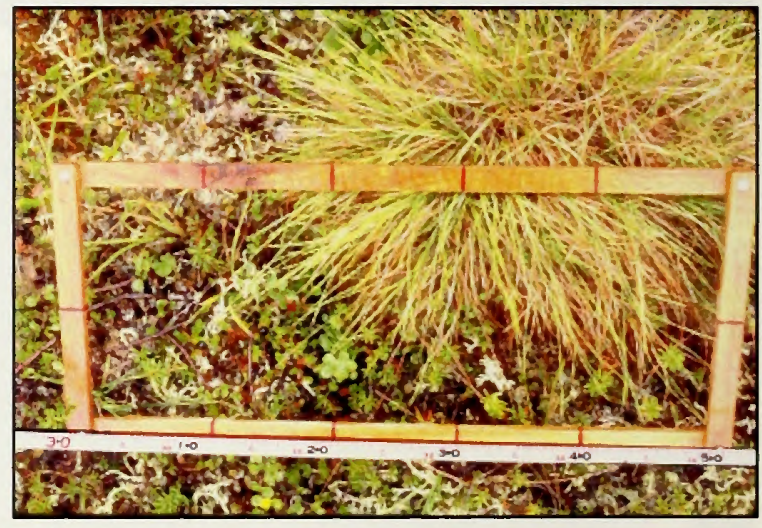

E-5. T1 Control-30m

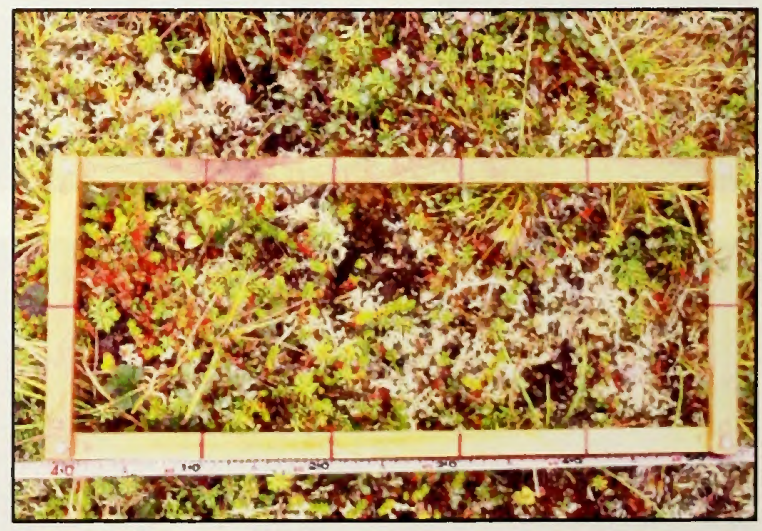

E-6. T1 Control-40m 


\section{Appendix F: Tundra fire recovery in western Alaska.}

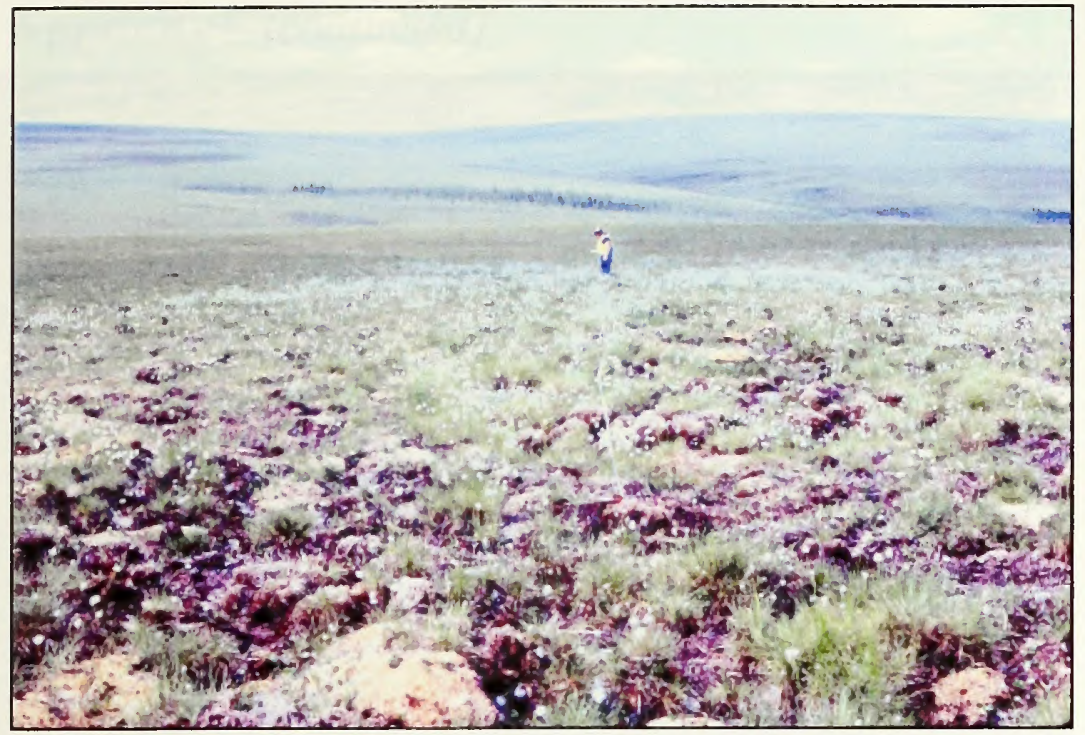

F-1. A vigorous cottongrass bloom marks the Ulukluk Creek burn area in 1983

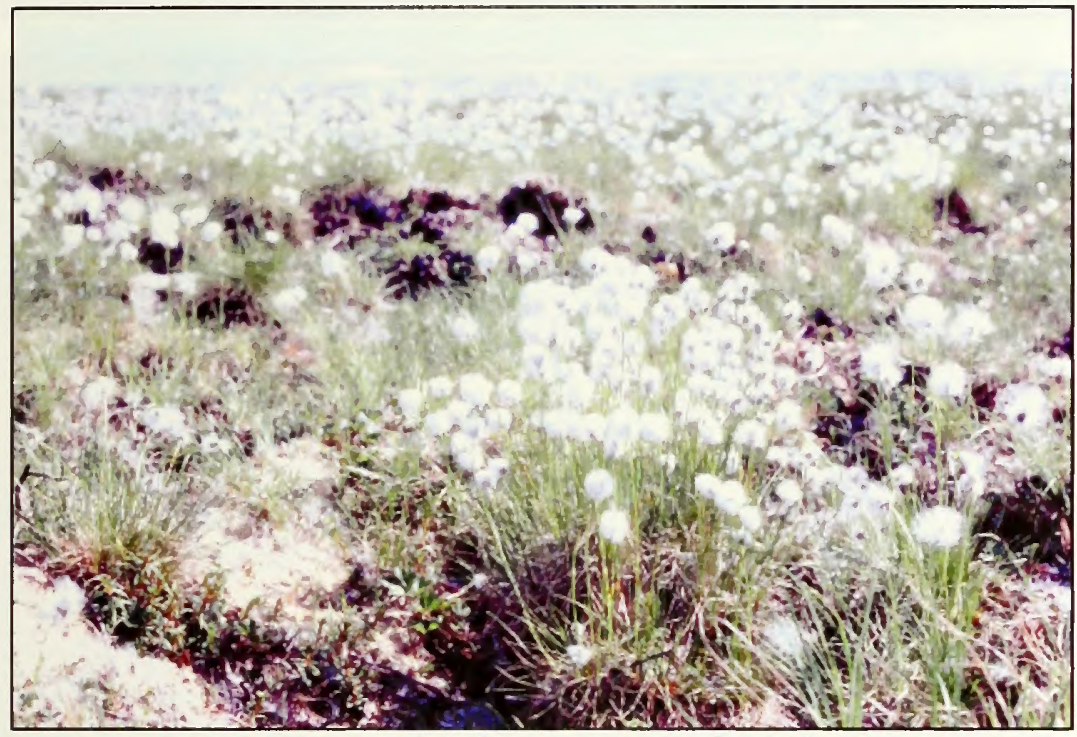

F-2. Close-up of flowering cottongrass at the Ulukluk Creek burn in 1983, the second season following fire.

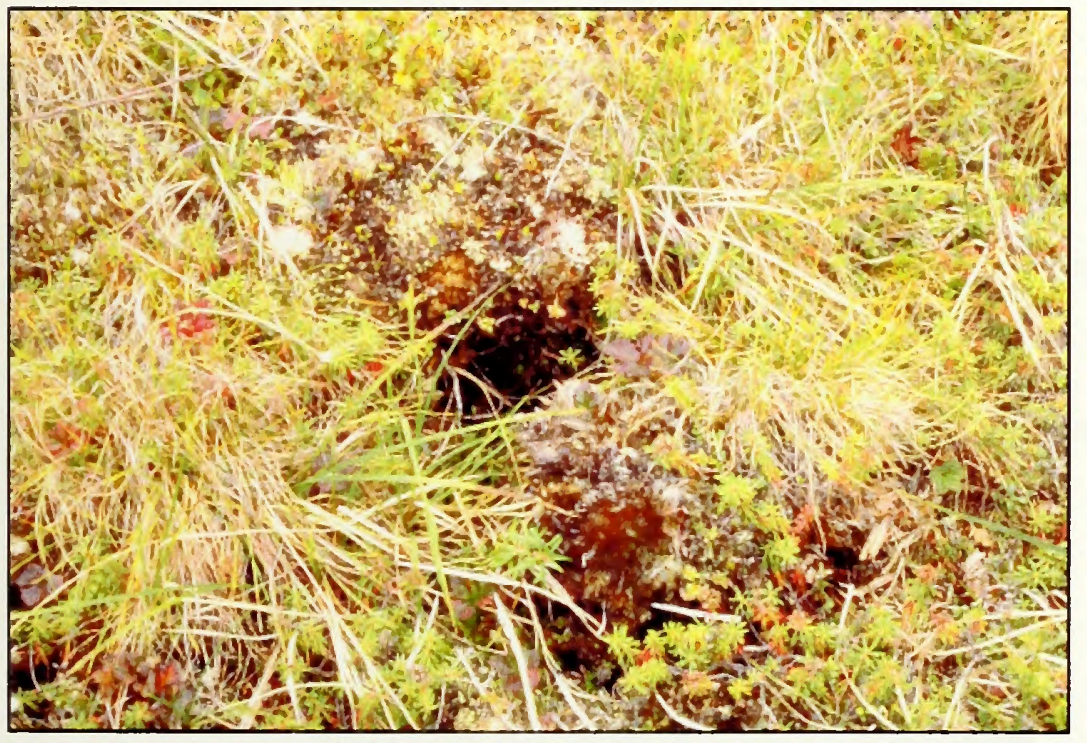

F-3. Early lichen regeneration on fire-damaged tussock in the Ulukluk Creek burn site, 1995. 


\section{Appendix F (continued)}

F-4. Dead Labrador tea (Ledum palustre) branches were a finding common to tundra burn sites aged 14-25 years. (Ulukluk Creek study site, 1995)

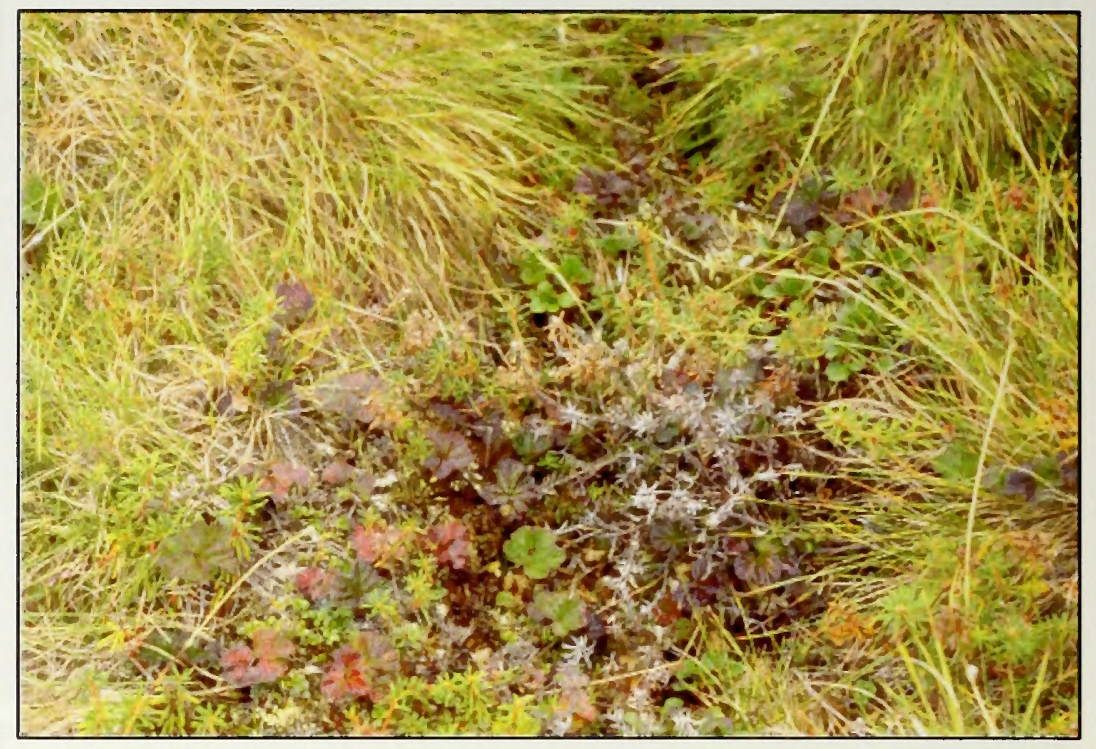

F-5. Large, vigorous tussocks of cottongrass were a finding common to tundra burn sites aged 14-25 years. (Ulukluk Creek study site, 1995)

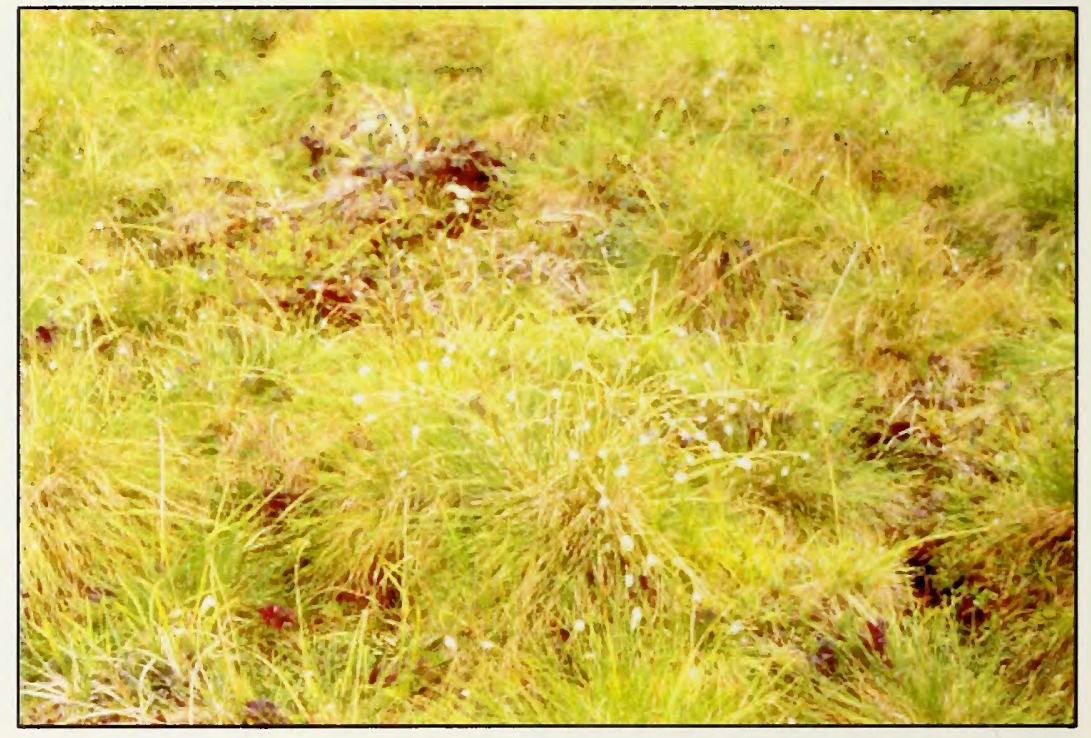

F-6. A fire-damaged tussock from a 1972 fire in the Buckland Valley demonstrating early regeneration of lichens 24 years after fire. Early growth forms of lichen (squamules) are difficult to identify to species. (Fire \#8719, 1996)

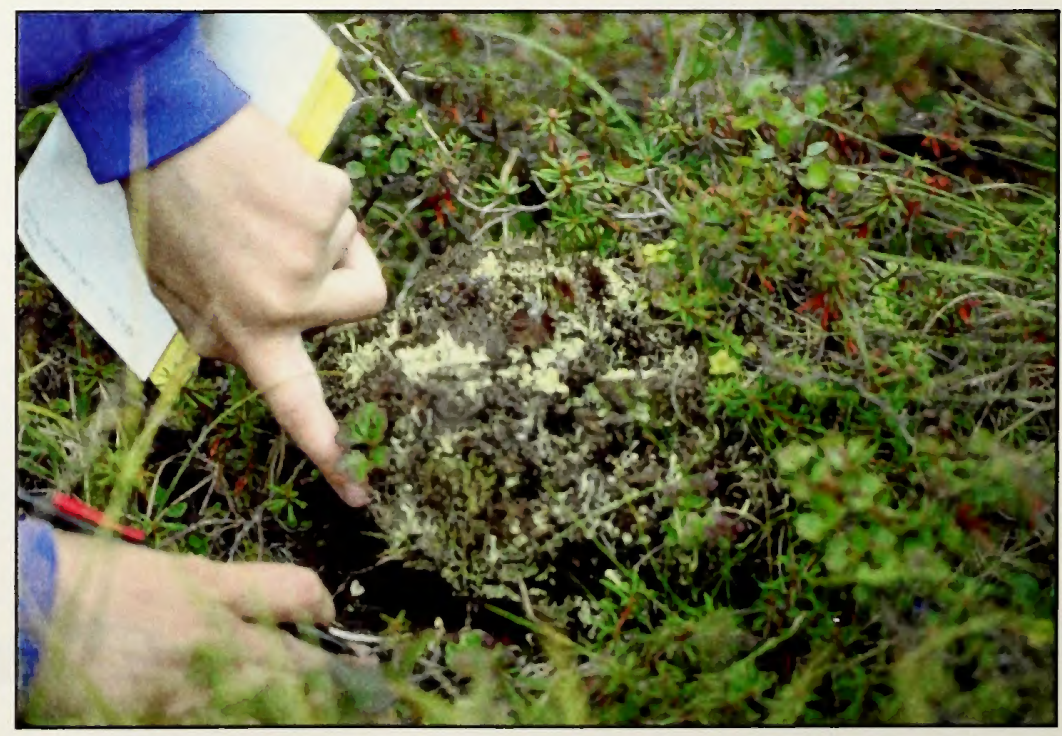


Appendix F (continued)

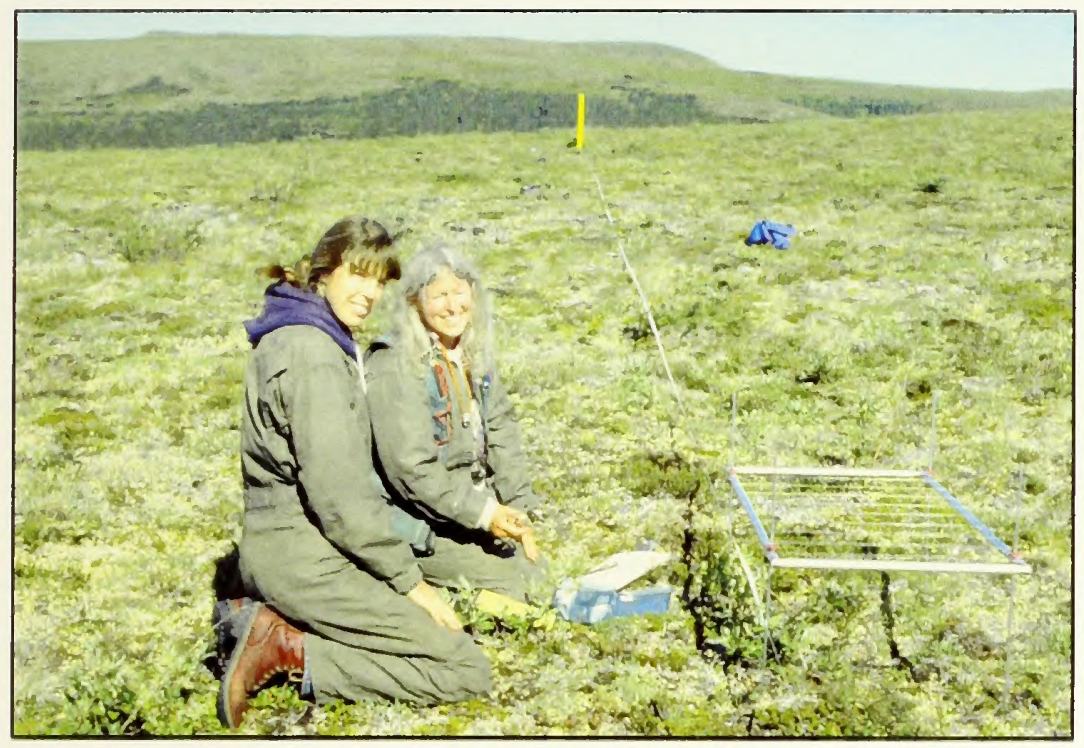

F-7. Investigators using pointsampling frame with 50 string-intersection grid to estimate vegetative cover at burn and control sites. (R.R. Jandt and C.R. Meyers 1996) 



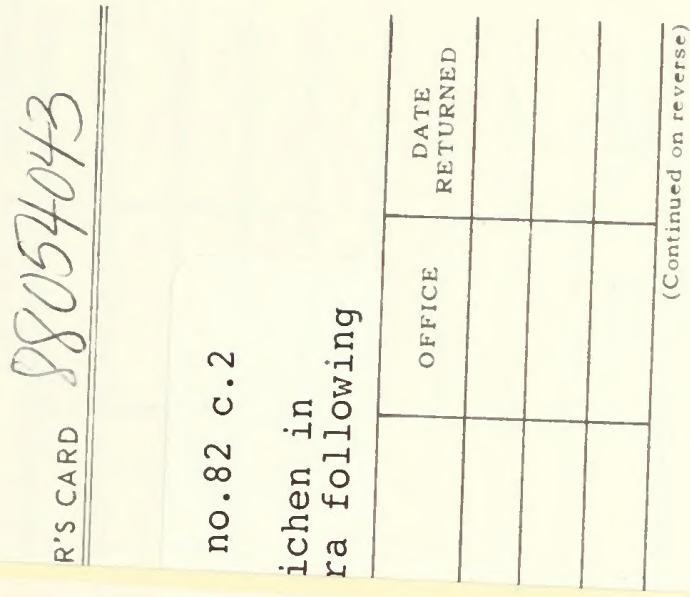

JK 870 .L3 O6 no.82 c.2

Recovery of lichen in

tussock tundra following

\section{BLM LIBRARY \\ BLDG 50, ST-150A \\ DENVEA FEDERAL CENTER \\ P.O. BOX 25047 \\ DENVER, COLORADO 80225}


